\title{
Integrative analysis of exogenous, endogenous, tumour and immune factors for precision medicine
}

\author{
Shuji Ogino, 1,2,3,4 Jonathan A Nowak, ${ }^{1}$ Tsuyoshi Hamada, ${ }^{2}$ Amanda I Phipps, ${ }^{5,6}$ \\ Ulrike Peters, ${ }^{5,6}$ Danny A Milner Jr, ${ }_{1}^{7}$ Edward L Giovannucci, ${ }^{3,8,9}$ Reiko Nishihara, 1,3,4,8,10 \\ Marios Giannakis, ${ }^{4,11,12}$ Wendy S Garrett, 4,11,13 Mingyang Song $8,14,15$
}

For numbered affiliations see end of article.

\section{Correspondence to} Dr Shuji Ogino, Program in MPE Molecular Pathological Epidemiology, Brigham and Women's Hospital, Boston, MA 02215,USA; shuji_ogino@dfci. harvard.edu

Received 24 October 2017 Revised 2 January 2018 Accepted 5 January 2018 Published Online First 6 February 2018
Check for updates

To cite: Ogino S, Nowak JA, Hamada T, et al. Gut 2018:67:1168-1180.

\section{ABSTRACT}

Immunotherapy strategies targeting immune checkpoints such as the CTLA4 and CD274 (programmed cell death 1 ligand 1, PD-L1)/PDCD1 (programmed cell death 1, PD-1) T-cell coreceptor pathways are revolutionising oncology. The approval of pembrolizumab use for solid tumours with high-level microsatellite instability or mismatch repair deficiency by the US Food and Drug Administration highlights promise of precision immuno-oncology. However, despite evidence indicating influences of exogenous and endogenous factors such as diet, nutrients, alcohol, smoking, obesity, lifestyle, environmental exposures and microbiome on tumour-immune interactions, integrative analyses of those factors and immunity lag behind. Immune cell analyses in the tumour microenvironment have not adequately been integrated into large-scale studies. Addressing this gap, the transdisciplinary field of molecular pathological epidemiology (MPE) offers research frameworks to integrate tumour immunology into population health sciences, and link the exposures and germline genetics (eg, HLA genotypes) to tumour and immune characteristics. Multilevel research using bioinformatics, in vivo pathology and omics (genomics, epigenomics, transcriptomics, proteomics and metabolomics) technologies is possible with use of tissue, peripheral blood circulating cells, cellfree plasma, stool, sputum, urine and other body fluids. This immunology-MPE model can synergise with experimental immunology, microbiology and systems biology. GI neoplasms represent exemplary diseases for the immunology-MPE model, given rich microbiota and immune tissues of intestines, and the well-established carcinogenic role of intestinal inflammation. Proof-of-principle studies on colorectal cancer provided insights into immunomodulating effects of aspirin, vitamin D, inflammatory diets and omega-3 polyunsaturated fatty acids. The integrated immunologyMPE model can contribute to better understanding of environment-tumour-immune interactions, and effective immunoprevention and immunotherapy strategies for precision medicine.

\section{INTRODUCTION}

Accumulating evidence indicates that innate and adaptive immunity profoundly influences the evolution of neoplasms. ${ }^{1-3}$ While cancer comprises transformed neoplastic cells that have accumulated somatic molecular alterations, there is a dynamic interplay of neoplastic and non-neoplastic cells including inflammatory and immune cells. A fraction of somatic mutations may result in the generation of new antigens (neoantigens) that can be recognised as non-self by the immune system. During an individual's life-course, cells may acquire somatic molecular alterations, and some of these cells undergo clonal expansion, displaying hallmarks of early neoplasia. Many of these cells are likely kept in check or killed by the host immune system before they can develop into clinically detectable tumours. By the time a tumour is detected, it has often acquired mechanisms to suppress immune responses and evade host immune surveillance. These processes are referred to as cancer immunoediting.

Cancer immunology is a blossoming field that has garnered well-deserved attention because of the success of immunotherapy approaches that target immune checkpoint mechanisms such as the CTLA4 and CD274 (programmed cell death 1 ligand 1, PD-L1)/PDCD1 (programmed cell death 1, PD-1) pathways. ${ }^{4}$ Many types of cancers misappropriate physiologic immune checkpoint mechanisms to evade immune-mediated recognition and destruction. Notably, blockade of immune checkpoints has proven successful in treating multiple tumour types, underscoring the power of the immune system to keep neoplasia in check. Additional active areas within cancer immunology include the development of cancer vaccines, adoptive cell therapy and immunisation for prevention and therapy. ${ }^{5-8}$

The immune system and inflammation undoubtedly play an important role in cancer aetiology as indicated by IBD-associated cancers and post-transplant malignancies due to long-term immunosuppression. Hence, primary cancer prevention is possible through the use of the immune system. ${ }^{5}{ }^{9}$ Evidence indicates that modifiable factors such as non-steroidal anti-inflammatory drug (NSAID) use, obesity, physical activity, cigarette smoking and systemic vitamin D levels influence cancer risk and outcome as well as immune system function. ${ }^{10-17}$ Hence, dietary, lifestyle and pharmacological immunomodulators may be used to enhance the immune system for cancer prevention and treatment.

Due to these multifaceted interactions, a comprehensive understanding of neoplasia requires a robust interrogation of the environment (inclusive of the exposome, ie, the totality of the exposures to various exogenous and endogenous factors) given environmental effects on both host immunity and neoplasms (illustrated in figure 1). Expert panels have recommended that integrative 


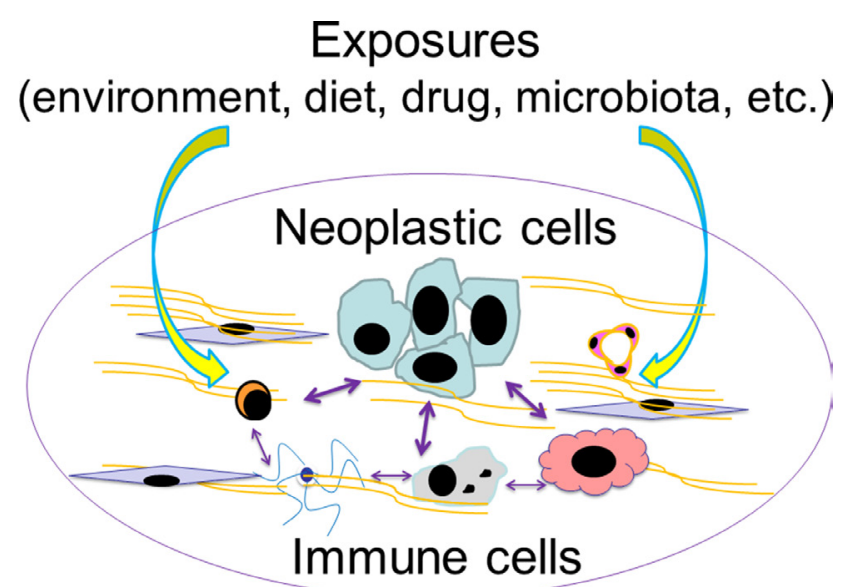

Figure 1 Various exogenous and endogenous factors (collectively called 'exposures') influence a tumour that has intrinsic and interacting components of neoplastic cells and the immune system. For simplicity, this does not depict complex interactions between the exposures and between neoplastic cells. There are ample research opportunities to decipher the interactions between these factors and components in human subjects and populations for better understanding of neoplasms. This figure illustrates potentials of integration of immunology and molecular pathological epidemiology.

transdisciplinary studies of modifiable exposures, tumour characteristics (including tumour omics and immunity) and clinical outcomes are urgently needed to improve strategies for precision prevention and treatment. ${ }^{918-21}$ However, this area of research is still in its infancy. We propose an integrated multilevel analysis of environment, tumour and immunity for improving cancer prevention and treatment. In this review, we discuss values and potentials of new approaches of integrating cancer immunology into pathobiology-based population health science.

\section{CANCER IMMUNOLOGY AND PRECISION MEDICINE}

The immune system is complex, consisting of many different and interacting cell types, which include (but are not limited to) T cells, B cells, NK cells, dendritic cells, macrophages, mast cells, polymorphonuclear neutrophils, eosinophils, basophils and other lymphoid and myeloid cells. While the importance of immunity for cancer is well recognised, the complexities of the immune system make its measurement and evaluation challenging in the clinical setting. Hence, clinical testing on tumour immunity have lagged behind tumour molecular testing for which the guidelines have been well developed. ${ }^{22}$ The clinical implications of the abundance and activities of various immune cell types in tumour tissue may vary in different tumour types. For example, intratumoural $\mathrm{FOXP}^{+}{ }^{+}$regulatory $\mathrm{T}$ cells (Tregs) may have a different prognostic significance in different tumour types. ${ }^{2324}$ In addition, heterogeneity in immune cell distribution and action can be influenced by local tumour cells, stroma and microenvironmental factors, including the microbiota. ${ }^{25}$ Spatial heterogeneity of the immune response poses further challenge when analysis is performed on small biopsy specimens rather than large resection specimens.

Despite these challenges, there are ample opportunities to develop clinically useful cancer immunology assays. For instance, international efforts have recently started to standardise immune cell analysis in cancer tissue; one of such efforts is the 'immunoscore' project, ${ }^{26} 27$ with an independent proof-of-principle study. ${ }^{28}$ In addition, a comprehensive evaluation of tumour immunity necessitates analyses of both tumour and immune cells. ${ }^{29}$ A number of tumour molecular analyses have been used in clinical practice, and tumour immunity evaluation can add prognostic information beyond tumour molecular features. ${ }^{24} 30$ For example, high-level microsatellite instability (MSI) and a high neoantigen load in colorectal cancers have been associated with a robust immune response and favourable clinical outcomes. ${ }^{31-34}$ MSI-high phenotype or mismatch repair deficiency predicts response to PDCD1 (PD-1) immune checkpoint blockade. ${ }^{35} 36$ Since May 2017, the US Food and Drug Administration (FDA) has approved use of the anti-PDCD1 (PD-1) antibody pembrolizumab for MSI-high or mismatch repair-deficient solid tumours regardless of primary organ site of tumour (https://www.fda.gov/ drugs/informationondrugs/approveddrugs/ucm560040.htm; last visited on 5 December 2017). This represents the first FDA approval of a drug indication based solely on tumour molecular testing without consideration of primary body or organ site. Thus, MSI status (or mismatch repair protein expression) is now an established predictive biomarker of GI cancers for response to immune checkpoint inhibition.

Regarding other immune-related tumour markers, analyses of immune checkpoint pathways have become common for targeted immunotherapies. Some tumours express immune checkpoint ligands, including CD274 (PD-L1) and PDCD1LG2 (PD-L2), to suppress antitumour immunity. ${ }^{2}$ These ligands can bind to the T cell surface receptor PDCD1 (PD-1) and downregulate the immune response. In multiple cancers including melanoma, renal cell carcinoma, lung carcinoma, gastric carcinoma, lymphomas and other malignancies, blockade of the immune checkpoint pathway provides an effective treatment strategy. Accumulating evidence indicates that activation of the PI3K signalling pathway (by EGFR mutation, PTEN loss, PIK3CA mutation, etc) can upregulate CD274 expression in various tumour types. ${ }^{3-40}$ These tumour molecular features can be combined with immune cell status in tumour tissues, to subclassify tumours for precision intervention strategies. ${ }^{41} 42$ In addition to the immune checkpoint ligand-receptor interactions, some cancers have been shown to upregulate certain metabolic enzymes including IDO1 (indoleamine 2,3-dioxygenase 1), TDO2 (tryptophan 2,3-dioxygenase) and ARG1 (arginase 1) that can skew the immune response to suppress antitumour immunity. ${ }^{43-47}$ IDO1 expression in cancers has been associated with the levels of T cell infiltrates. ${ }^{48} 49$ Evidence also suggests that enhanced tumour cell metabolism depletes specific nutrients in the tumour microenvironment, which in turn, can suppress immune response and lead to tumour progression. ${ }^{50}$

To accelerate translation of our growing knowledge about cancer immunology into precision medicine, further efforts are needed to develop integrative tumour molecular pathology and immunity tests that can be useful for clinical and public health practices. To ensure rigour and reproducibility of these efforts, we cannot overemphasise the importance of data sciences, including epidemiology. The field of epidemiology primarily concerns methods of designing studies and analysing biomedical health data. Essentially, all clinical studies explicitly or implicitly rely on epidemiological principles to ensure the internal and external validity of results. Misuse or failure to properly use epidemiological and statistical principles is one of major reasons for non-reproducible study findings. ${ }^{51}$ Hence, the epidemiological principles must be properly used in clinical and translational research studies to promote robust evidence-based precision medicine. 


\section{Hypothesis testing \#1}

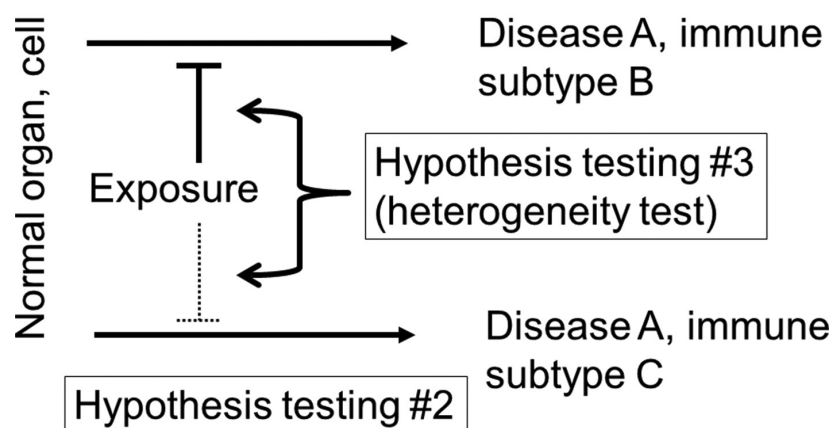

Figure 2 Hypothesis testing in molecular pathological epidemiology (MPE) in a study of immune subtypes of disease A, with the simplest binary subtyping (subtypes B and C). Note that disease subtyping systems are often more complicated than simple dichotomy. Hypothesis testing \#1 or \#2 is on the relationship between an exposure of interest and each subtype. In this illustration, the exposure is hypothesised to prevent subtype B. Hypothesis testing \#3 is unique to MPE, and concerns on a difference (heterogeneity) between the relationships of the exposure with the immune subtypes B and C.

\section{MOLECULAR PATHOLOGICAL EPIDEMIOLOGY- INTEGRATING MOLECULAR AND POPULATION-LEVEL SCIENCE}

Although molecular pathology analyses had been used in epidemiological research on non-communicable diseases since the 1990s, a more complete integration of pathology and epidemiology occurred only relatively recently. ${ }^{52}$ Molecular pathology has become a major subfield of pathology with molecular pathology diagnostics now playing a routine part in clinical practice. By virtue of advances in molecular pathology, disease classification systems have transformed patient treatment and management. Molecular pathological information can also transform epidemiology. Advances in molecular pathology have enabled testing of targeted epidemiological hypotheses based on biological mechanisms. This trend necessitates the development of new research frameworks and analytic methodologies to decipher disease at both the molecular and population levels. ${ }^{52}$

In parallel with this trend, the integration of molecular pathology and epidemiology has led to the emergence of the transdisciplinary field of 'molecular pathological epidemiology (MPE)'. ${ }^{53-56}$ The MPE approach aims to connect potential risk factors to the molecular pathology of disease. As outcome variables, MPE research deals with disease incidence and mortality as well as health conditions and biomarkers that can predict future disease development or manifestations. ${ }^{57-59}$ Figure 2 illustrates the general approach that is typically taken for MPE research, using immune analysis as an example. The conceptual and practical rationale for hypothesis testing in MPE research has been described in detail elsewhere. ${ }^{556061}$ Statistical analysis methods have been developed to test hypotheses on aetiological heterogeneity between disease subtypes in various study design settings, ${ }^{60-69}$ and to address missing data in MPE research. ${ }^{70}$ The paradigm of MPE has been widely recognised in the literature. $^{71-113}$ Its relevance has been discussed in well-established scientific society meetings, ${ }^{114-117}$ and in the International MPE Meeting Series. ${ }^{118} 119$

The MPE approach can contribute to precision medicine. Aspirin has been associated with reduction of colorectal cancer incidence and mortality. ${ }^{120-125}$ MPE analyses of patient survival have suggested potential of aspirin as a therapeutic agent specifically for PTGS2 (cyclooxygenase-2)-overexpressing colorectal cancers, ${ }^{126} 127$ PIK3CA-mutated colorectal cancers ${ }^{128-130}$ and CD274 (PD-L1)-low colorectal cancers. ${ }^{131}$ Some of these markers may be used to select patients for aspirin therapy. Because these MPE analyses have been based on observational cohorts, prospective clinical trials have been ongoing. ${ }^{76}$

MPE analyses to assess cancer incidence can also contribute to precision prevention. ${ }^{11} 1321{ }^{132-134}$ Although colonoscopy screening has been associated with lower incidence of colorectal cancer, it may be less effective for MSI-high, CpG island methylator phenotype (CIMP)-high and BRAF-mutated colorectal cancers as high levels of MSI and CIMP and BRAF mutations are common features of postcolonoscopy (or interval) colorectal cancers. ${ }^{135-138}$ MPE studies have shown that smoking is associated with increased risk of MSI-high, CIMP-high and BRAF-mutated colorectal cancers. ${ }^{139-143}$ These lines of evidence may raise a question whether tobacco smokers may need improved colonoscopy or other screening procedures. It is expected that future MPE analyses can reveal additional links of certain risk factors and specific disease subtypes, which will contribute to the development of precision prevention strategies.

Moreover, MPE is a versatile method-based discipline that can enhance other scientific fields by means of developing unique analytical frameworks and methodologies. For instance, MPE can be integrated into social science ${ }^{144}$ and pharmacology. ${ }^{145}$ In particular, integration of pharmacology and MPE can decipher the influence of common medications on incidence and progression of disease subtypes. ${ }^{128}{ }^{146-149}$ Similarly, integration of immunology and MPE can also be achieved as detailed below.

\section{MPE HELPS ESTABLISH CAUSALITY}

Epidemiological associations between lifestyle factors and cancer risks are relatively weak because traditional epidemiological studies generally use overall organ-specific cancers as a single outcome, and controversies have existed on causality in many of the associations. ${ }^{54}$ By means of connecting an exposure to specific molecular pathology, MPE research can provide pathogenic insights, and determine the strength of the association for the specific subtype, thereby helping establish causality. ${ }^{54} 150$ MPE research can reveal hidden structures of causal relationships, which may not be observed in conventional epidemiological research. ${ }^{150}$ For example, in the so-called obesity paradox, obesity is associated with better clinical outcome among patients with a disease that is caused (at least in part) by obesity. Such paradoxical findings on obesity lead to confusion and questions on causality of the relationship, hindering the development of public health measures for obesity prevention. On the other hand, MPE research can provide unique insights into paradoxical observations. For example, studies on renal cell carcinoma have shown such paradoxical findings. ${ }^{151}$ MPE research has shown that obesity is associated with $F A S N$-non-expressing subtype of renal cell carcinoma, which in turn is associated with better clinical outcome compared with FASN-overexpressing subtype. ${ }^{152}$ Hence, MPE research can potentially decipher paradoxical findings in conventional epidemiological research. ${ }^{150}$

It is also important to acknowledge limitations of observational studies in establishing causality. Hence, in addition to rigorous study design and analyses, the importance in acquiring multiple lines of evidence from research using different experimental biological models and different study settings, including experimental clinical trials, should be recognised. 
Exposures

(e.g., diet, drug,

germline genetics)

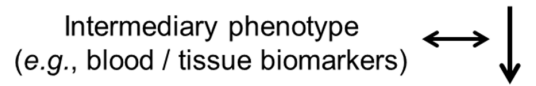

Disease status at diagnosis (molecular pathology, immune status)

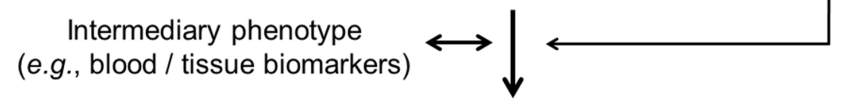

Downstream outcome

(e.g., recurrence, mortality)

Figure 3 Overview of research designs to integrate immunity analyses into the framework of molecular pathological epidemiology. The word 'exposures' is broadly used as an epidemiological term for variables that can causally influence disease incidence, status or outcome. Immunity assessments include germline genotyping of immune-related genes, analyses of immunity status in disease tissue and analyses of biomarkers on tissue, blood and/or other body fluids as intermediary phenotypes. Intermediary phenotypes refer to phenotypes that are thought to precede full-blown disease phenotypes or subsequent clinical outcome (eg, mortality), and can be typically assessed in radiological images, biopsy tissue, peripheral blood or other body fluids. Intermediary phenotype variables can be used as exposures or outcomes in epidemiological terms.

\section{INTEGRATING IMMUNOLOGY INTO MPE}

In this section, we discuss the integration of cancer immunology and MPE.

\section{The scientific link between MPE and immunology}

MPE research addresses the interpersonal heterogeneity of disease processes and pathogenesis. ${ }^{53118}$ As the unique disease principle ${ }^{153154}$ indicates, a pathological process in each person is uniquely influenced by a combination of exogenous and endogenous factors, and their interactions with both disease cells and normal cells including immune cells. It is assumed that individuals with diseases that share similar molecular pathological features also share similar aetiologies. ${ }^{153}$ Accordingly, subclassification of patients based on similarities (and dissimilarities) of pathological and immunological markers may enable researchers to link putative risk factors to specific pathologies, including altered immune status. Ample evidence indicates an influence of tumour molecular pathological alterations on immune response to tumour, and an influence of immune status on biological aggressiveness and progression of tumour. ${ }^{24} 26-29155156$ Exogenous and endogenous factors can modify the biological nature of a given tumour that has intrinsic and interacting components of neoplastic cells and the immune system (figure 1). In this sense, immunology can be considered an integral part of MPE at the conceptual level, with the potential for providing valuable new insights when integrated into MPE at the practical level.

In addition, the importance of immunity analysis in human tissue cannot be overemphasised, because even the best animal models cannot fully recapitulate the human immune system or complex diseases. ${ }^{157}$ Hence, experimental immunology research on model systems need to be corroborated and augmented by human tissue and population research and vice versa.

\section{How can immunology be integrated into MPE?}

MPE research has been most commonly applied to neoplastic diseases. $^{55}$ Neoplastic diseases provide us with clonally expanded cells for molecular analyses in both clinical practice and MPE research settings. However, analyses of immunity status in tumour tissue have been uncommon in epidemiology despite the important role of immunity in cancer. This is in part because immune cell assessment in tumour tissue has not been a common clinical test, and it remains a considerable challenge to accurately and reproducibly evaluate the interactions between the tumour and immune cells. Furthermore, in a typical population-scale research setting, it is not always practical or feasible to incorporate detailed characterisation of tumours beyond information present in medical records. Assessment of immune cells in tumour tissue currently requires considerable effort from a pathologist. Hence, the integration of immunological assessment of tissue into epidemiological studies remains limited.

Likely, the most commonly used immune-related analysis method in epidemiology settings is germline genetic testing. For example, specific $H L A$ genotypes have been associated with risks for certain autoimmune disorders, including ankylosing spondylitis, rheumatoid arthritis and multiple sclerosis. Numerous genes and gene variants (including those in HLA loci) play roles in immune response to various antigens including microbial proteins and tumour neoantigens. Analysis of immune cells and inflammatory markers in peripheral blood specimens is another method that can provide information on systemic inflammation and immune status and is commonly used in epidemiological research. Nonetheless, germline genetic and peripheral blood analyses yield only limited information on the status of interactions between tumour and immune cells in the local tumour microenvironment. Immune cells in the normal colon mucosa and colorectal cancer tissue show substantial phenotypic differences compared with the same immune cell type isolated from the peripheral blood from the same individual. ${ }^{158} 159$ Hence, analysis of immune cells in the relevant tissue is essential to understand immune cells in the tumour microenvironment. ${ }^{160}$ Importantly, integrative multilevel analyses (including omics technologies) of available biospecimens, including germline DNA, peripheral blood cells, circulating molecules, microbes, neoplastic cells and immune cells in the local microenvironment can provide a better, holistic view of immune status within an individual and in relation to a tumour, compared with analysis of any single source of information. Ultimately, the full integration of immunology into MPE will help us gain considerable insights into cancer as a disease of immune dysfunction.

\section{Integrative 'immunology-MPE' research model}

As discussed above, the integration of immunology and MPE is a natural extension of MPE. It can generate insights into how lifestyle, dietary, genetic, microbial and environmental exposures influence disease processes through impacting the immune system and disease-immune interactions. Although data are currently scarce in this emerging area, this field is expected to expand in light of the increasing importance of cancer immunology. Figure 3 illustrates the multilevel framework of immunology-MPE research. Assessment of immunity can be performed using multilevel and multidimensional approaches, using germline genotypes, immune biomarkers in blood or other body fluids and normal and disease tissues of interest to evaluate the immune status in the tissue microenvironment. Immunology-MPE can and should synergise with basic experimental immunology, as these two research models offer complementary strengths (table 1).

Research on GI neoplasms, especially colorectal carcinoma, has considerable relevance in this emerging immunology-MPE 
Table 1 Comparisons of basic experimental immunology and immunology-molecular pathological epidemiology (MPE)

\begin{tabular}{|c|c|c|}
\hline & Basic experimental immunology & Immunology-MPE \\
\hline Research subjects & Immune system in in vivo or in vitro models & Human populations \\
\hline Exposure data (diet, lifestyle, medications, etc.) & Easily control and record exposure data & Possible to collect exposure data \\
\hline Control of environmental or other conditions & Yes & Difficult; a targeted control can be done by randomised trials \\
\hline Evaluation of the human immune system & $\begin{array}{l}\text { Can be done using human immune cells. It is still a challenge } \\
\text { to recapitulate the human immune system in experimental } \\
\text { models. Encompassing the complexity of systemic and local } \\
\text { tumour-related immunity is difficult. }\end{array}$ & $\begin{array}{l}\text { Can be done. It is still a challenge to evaluate immunity status } \\
\text { in the local microenvironment if access to tissue is difficult. } \\
\text { Encompassing the complexity of systemic and local tumour- } \\
\text { related immunity may be possible. }\end{array}$ \\
\hline In vivo evaluation & Possible & $\begin{array}{l}\text { Difficult; can be done by in vivo pathology or molecular } \\
\text { imaging }\end{array}$ \\
\hline Large sample size & Difficult & Possible \\
\hline Insight into mechanisms & Possible & $\begin{array}{l}\text { Immunology-MPE can provide mechanistic insights, which } \\
\text { need to be verified by basic experimental research }\end{array}$ \\
\hline Generalisability and validity in humans & $\begin{array}{l}\text { Generalisability and validity of findings from model systems } \\
\text { need to be examined in human populations }\end{array}$ & $\begin{array}{l}\text { As research on human populations, immunology-MPE can be } \\
\text { a validation method for findings from experimental research }\end{array}$ \\
\hline
\end{tabular}

area. GI neoplasms represent exemplary diseases to use this integrative research model. The digestive tract, especially the colon and rectum, has rich microbiota and immune tissues and is accessible by endoscopies. It is also sensitive to tumour-promoting effects of inflammation, as illustrated by the link between IBD and colorectal cancer. Furthermore, the external environment, including immune-related lifestyle factors, appears to have a stronger role in the development of GI cancers compared with many other types of malignancies. Colorectal cancer is a molecularly heterogenous group of neoplasms, ${ }^{161-168}$ which are influenced by exogenous and endogenous factors and immune response to tumour. ${ }^{54} 169-172$ Epigenetics can mediate effects of exposures on tumour plasticity and phenotypes. ${ }^{153}$ 173-178 The continuum of differences in clinical and molecular characteristics of colorectal neoplasms according to bowel subsites is compatible with the interactive roles of the microbiota and immunity in colorectal carcinogenesis. ${ }^{179-191}$ As immunoediting appears to be a common event during colorectal carcinogenesis, a subset of colorectal carcinomas have been shown to overexpress CD274 (PD-L1) ${ }^{31}{ }^{192-201}$ and PDCD1LG2 (PD-L2). ${ }^{202}$ However, immune checkpoint blockade has not been shown to be effective against most colorectal carcinomas, except for MSI-high (mismatch repair deficient) tumours. ${ }^{156} 203204$ There are thus ample opportunities for the development of effective interventions, including immunoprevention and immunotherapy strategies against colorectal cancer. ${ }^{204} 205$

Colorectal cancer has been commonly studied in MPE research. ${ }^{54206207}$ There is an increasing trend of assessments of immune response to colorectal carcinoma, in addition to tumour molecular analyses, in the context of large-scale population-based studies. ${ }^{194}$ 208-219 Table 2 lists proof-of-principle immunology-MPE studies on potential aetiological factors that may influence incidence of immune subtypes of cancer; below, we highlight several notable findings.

One study, using resources of the Nurses' Health Study (NHS) and the Health Professionals Follow-up Study (HPFS), showed that a higher intake of marine omega- 3 polyunsaturated fatty acids ( $\omega-3$ PUFA, rich in fish) was associated with a lower risk of colorectal cancer containing high-density $\mathrm{FOXP}^{+}$cells in tissue, but not with risk of colorectal cancer containing low-density $\mathrm{FOXP}^{+}{ }^{+}$cells. ${ }^{220}$ Possibly, $\omega-3$ PUFA may downregulate the function of $\mathrm{FOXP}^{+}$Treg cells, thereby enhancing the antitumour function of effector $\mathrm{T}$ cells even in the presence of abundant $\mathrm{FOXP}^{+}{ }^{+}$cells. ${ }^{220}$ Consistent with this hypothesis, an in vitro experiment using coculture of naïve $C D 4^{+} \mathrm{T}$ cells and colonic
$\mathrm{FOXP}^{+}$Treg cells revealed that exposure to high $\omega-3$ PUFA concentrations led to downregulation of $\mathrm{FOXP}^{+}$cell function, which resulted in increased naïve $C D 4^{+} \mathrm{T}$ cell proliferation. ${ }^{220}$ As exemplified by this study, ${ }^{220}$ immunology-MPE research can synergise with basic experimental immunology research.

A second study ${ }^{221}$ based on the Genetics and Epidemiology of Colorectal Cancer Consortium (GECCO) examined whether risk alleles for IBD identified by genome-wide association studies (GWAS) might be associated with colorectal cancer risk (figure 4). Although risk alleles for IBD, a well-established colorectal cancer risk factor, are conceivably also risk alleles for colorectal cancer, none of GWAS-identified IBD risk alleles was detected as a risk allele for colorectal cancer by agnostic GWAS. ${ }^{222}$ Using over 25000 cases and controls, one IBD risk allele (rs11676348) was associated weakly with colorectal cancer with an OR (per allele) of 1.08 (95\% CI 1.04 to 1.12$)^{221}$; notably with this effect size, this polymorphism was not detected by an agnostic GWAS approach. Interestingly, when immune response to colorectal cancer was examined, the rs11676348 allele was associated with colorectal cancer exhibiting Crohn's-like lymphoid reaction (with the OR 1.47; 95\% CI 1.01 to 2.13 ) but not with cancer exhibiting no Crohn's-like reaction. ${ }^{221}$ Crohn's-like lymphoid reaction refers to transmural lymphoid aggregates that mimic Crohn's disease (one manifestation of IBD). ${ }^{208}$ As Crohn's-like reaction is associated with MSI-high colorectal carcinoma, ${ }^{208}$ the differential association of the rs11676348 allele according to MSI status was examined, revealing a consistent differential association of the rs11676348 allele with MSI-high tumours, but not with non-MSI-high tumours, in two independent datasets within GECCO. ${ }^{221}$ Possible heterogeneity of aetiological associations according to cancer immune subtypes may explain why the rs11676348 polymorphism is only weakly associated with colorectal cancer overall. This approach enables us to find many uncovered risk alleles for various diseases. This study ${ }^{221}$ represents a proof-of-principle analysis of the GWAS-MPE approach $^{54}$ and immunology-MPE research.

A third study based on the NHS and the HPFS showed that high-level plasma vitamin D was associated with a lower risk of colorectal cancer with high-level lymphocytic infiltrates, but not with risk of colorectal cancer with low-level lymphocytic infiltrates. ${ }^{223}$ Hence, the cancer preventive effect of vitamin D appears to be stronger for cancer with high-level lymphocytic infiltrates. $^{223}$ Some immune cells are capable of converting 25-hydroxyvitamin $\mathrm{D}[25(\mathrm{OH}) \mathrm{D}]$ to bioactive $1 \alpha, 25$-dihydroxyvitamin $\mathrm{D}_{3}\left[1,25(\mathrm{OH})_{2} \mathrm{D}_{3}\right]$, which may prevent neoplastic 
Table 2 Immunology-molecular pathological epidemiology (MPE) studies on possible aetiological factors and incidence of neoplasia subgroups classified by immune response to tumour

\begin{tabular}{|c|c|c|c|c|c|c|}
\hline $\begin{array}{l}\text { First author, Year, } \\
\text { ref }\end{array}$ & Study design & $\begin{array}{l}\text { Cases with } \\
\text { tissue specimens } \\
\left(\text { sample size }^{*}\right)\end{array}$ & Study cohort & Exposure variables & Outcome variables & $\begin{array}{l}\text { Main findings on exposures } \\
\text { and risk of disease subtypes } \\
\text { classified by local tissue } \\
\text { immune status }\end{array}$ \\
\hline Cao $2016^{289}$ & $\begin{array}{l}\text { Prospective cohort } \\
\text { study }\end{array}$ & $\begin{array}{l}\text { Colorectal } \\
\text { cancer (1458 } \\
\text { cases in } 134981 \\
\text { participants) }\end{array}$ & $\begin{array}{l}\text { Health Professionals } \\
\text { Follow-up Study and } \\
\text { Nurses' Health Study }\end{array}$ & Aspirin use & $\begin{array}{l}\text { Incidence of } \\
\text { colorectal cancer } \\
\text { subtype classified by } \\
\text { lymphocytic infiltrates }\end{array}$ & $\begin{array}{l}\text { Regular aspirin use is associated } \\
\text { with lower incidence of } \\
\text { colorectal cancer subtype with } \\
\text { lower level tumour-infiltrating } \\
\text { lymphocytes (TIL) but not that of } \\
\text { subtype with higher level TIL. }\end{array}$ \\
\hline Hanyuda $2016^{290}$ & $\begin{array}{l}\text { Prospective cohort } \\
\text { study }\end{array}$ & $\begin{array}{l}\text { Colorectal cancer } \\
\text { (1436 cases during } \\
3346000 \text { person- } \\
\text { years of follow-up) }\end{array}$ & $\begin{array}{l}\text { Health Professionals } \\
\text { Follow-up Study and } \\
\text { Nurses' Health Study }\end{array}$ & Body mass index (BMI) & $\begin{array}{l}\text { Incidence of } \\
\text { colorectal cancer } \\
\text { subtype classified by } \\
\text { lymphocytic infiltrates }\end{array}$ & $\begin{array}{l}\text { BMI is not associated } \\
\text { differentially with risk of } \\
\text { colorectal cancer subtypes } \\
\text { classified by lymphocytic } \\
\text { infiltrates. }\end{array}$ \\
\hline Khalili $2015^{221}$ & $\begin{array}{l}\text { Nested case-control } \\
\text { study within prospective } \\
\text { cohort study (subgroup } \\
\text { analysis in consortium) }\end{array}$ & $\begin{array}{l}\text { Colorectal cancer } \\
\text { (288 cases and } \\
1172 \text { controls) }\end{array}$ & $\begin{array}{l}\text { Health Professionals } \\
\text { Follow-up Study } \\
\text { and Nurses' Health } \\
\text { Study (in Genetics } \\
\text { and Epidemiology } \\
\text { of Colorectal Cancer } \\
\text { Consortium) }\end{array}$ & $\begin{array}{l}\text { Genetic polymorphism } \\
\text { rs11676348 (risk allele } \\
\text { for inflammatory bowel } \\
\text { disease) }\end{array}$ & $\begin{array}{l}\text { Incidence of } \\
\text { colorectal cancer } \\
\text { subtype classified by } \\
\text { lymphocytic infiltrates }\end{array}$ & $\begin{array}{l}\text { The rs } 11676348 \mathrm{C} \text { allele is } \\
\text { associated with risk of colorectal } \\
\text { cancer subtype showing Crohn's } \\
\text { like lymphoid reaction but not } \\
\text { risk of subtype showing no } \\
\text { Crohn's-like reaction. }\end{array}$ \\
\hline Liu $2017^{291}$ & $\begin{array}{l}\text { Prospective cohort } \\
\text { study }\end{array}$ & $\begin{array}{l}\text { Colorectal } \\
\text { cancer (1311 } \\
\text { cases in } 124433 \\
\text { participants) }\end{array}$ & $\begin{array}{l}\text { Health Professionals } \\
\text { Follow-up Study and } \\
\text { Nurses' Health Study }\end{array}$ & $\begin{array}{l}\text { Dietary inflammatory } \\
\text { index }\end{array}$ & $\begin{array}{l}\text { Incidence of } \\
\text { colorectal cancer } \\
\text { subtype classified by } \\
\text { lymphocytic infiltrates }\end{array}$ & $\begin{array}{l}\text { Inflammatory diet is associated } \\
\text { with higher incidence of } \\
\text { colorectal cancer subtype } \\
\text { with lower level intratumour } \\
\text { periglandular reaction but not } \\
\text { that of subtype with higher level } \\
\text { reaction. }\end{array}$ \\
\hline Song $2016^{223}$ & $\begin{array}{l}\text { Nested case-control } \\
\text { study (within } \\
\text { prospective cohort } \\
\text { study) }\end{array}$ & $\begin{array}{l}\text { Colorectal cancer } \\
(318 \text { cases and } 624 \\
\text { controls) }\end{array}$ & $\begin{array}{l}\text { Health Professionals } \\
\text { Follow-up Study and } \\
\text { Nurses' Health Study }\end{array}$ & $\begin{array}{l}25 \text {-Hydroxyvitamin } D \text { in } \\
\text { plasma }\end{array}$ & $\begin{array}{l}\text { Incidence of } \\
\text { colorectal cancer } \\
\text { subtype classified by } \\
\text { lymphocytic infiltrates }\end{array}$ & $\begin{array}{l}\text { Level of plasma } \\
25 \text {-hydroxyvitamin D is } \\
\text { associated with lower risk of } \\
\text { colorectal cancer subtype with } \\
\text { high-level tumour-infiltrating } \\
\text { lymphocytes (TILs), but not with } \\
\text { risk of subtype with low-level } \\
\text { TILs. }\end{array}$ \\
\hline Song $2016^{220}$ & $\begin{array}{l}\text { Prospective cohort } \\
\text { study }\end{array}$ & $\begin{array}{l}\text { Colorectal } \\
\text { cancer (614 } \\
\text { cases in } 125172 \\
\text { participants) }\end{array}$ & $\begin{array}{l}\text { Health Professionals } \\
\text { Follow-up Study and } \\
\text { Nurses' Health Study }\end{array}$ & $\begin{array}{l}\text { Dietary intake } \\
\text { of omega-3 } \\
\text { polyunsaturated fatty } \\
\text { acids ( } \omega-3 \text { PUFA) }\end{array}$ & $\begin{array}{l}\text { Incidence of } \\
\text { colorectal cancer } \\
\text { subtype classified by } \\
\text { lymphocytic infiltrates }\end{array}$ & $\begin{array}{l}\text { Intake of } \omega-3 \text { PUFA is associated } \\
\text { with lower risk of colorectal } \\
\text { cancer subtype with high tissue } \\
F O X P 3^{+} \text {cell density, but not with } \\
\text { risk of subtype with low tissue } \\
F O X P 3^{+} \text {cell density. }\end{array}$ \\
\hline
\end{tabular}

Official symbols for genes and gene products including proteins are described in the HUGO Gene Nomenclature Committee (HGNC) website (www.genenames.org). Studies with

$<200$ cases with tissue data are not listed.

* Sample size is based on cases with available tissue data.

progression in individuals who can elicit high-level lymphocytic response to emerging tumours. ${ }^{223}$

\section{TRANSLATION INTO IMMUNOPREVENTION AND IMMUNOTHERAPY}

The integration of immunology and MPE can drive future research and clinical practice, to generate population-based evidence and novel insight for the development of effective immunotherapy and immunoprevention strategies. Immunoprevention (or immunoprophylaxis) embraces the use of immunomodulators and prophylactic vaccines. For example, the aforementioned research on $\omega-3$ PUFA and vitamin D suggests their roles in preventing cancer through immune mechanisms. If replicated, the findings of this immunology-MPE study may provide the rationale for the use of nutritional supplementation for cancer immunoprevention. Identification of a dietary, lifestyle or pharmacological factor that can effectively improve outcomes in a specific disease subtype (classified by immune status) may lead to an effective immunotherapeutic strategy for that subtype. Hence, in addition to targeted immunotherapeutic agents, immunomodulators may have a role in clinical immuno-oncology practice. A recent study has shown that use of aspirin is associated with better clinical outcome in colorectal cancers that do not overexpress the CD274 (PD-L1) immune checkpoint ligand, but not with outcome in CD274 (PD-L1)-overexpressing cancers, suggesting a possible synergistic effect of immune checkpoint blockade and aspirin. ${ }^{131}$ Hence, immunology-MPE research has substantial roles in the development and refinement of strategies of immunoprevention and immunotherapy.

\section{CHALLENGES}

Challenges exist in the emerging immunology-MPE field. Some of those are relevant to the field of MPE as previously described. ${ }^{54}$ First, sample size is generally limited based on biospecimen availability, which can also lead to selection bias. Hence, investigators should make efforts to increase sample size 


\section{rs11676348 IBD risk allele $\mathrm{OR}=1.08$ (very weak)}

\section{$\mathrm{OR}=1.47$ (modest) \\ rs11676348 Crohn's-like reaction $(+)$ subtype
IBD risk allele $\longrightarrow$ Crohn's-like reaction (-) subtype \\ $\mathrm{OR}=0.90$ (null)}

$(P$ for heterogeneity $=0.02)$

Figure 4 Illustration of the molecular pathological epidemiology approach using tumour immunity status. The germline DNA polymorphism rs11676348 is a risk allele for IBD. Because IBD is a risk factor for colorectal cancer, the rs 11676348 polymorphism is considered to be a risk factor for colorectal cancer. The Genetics and Epidemiology of Colorectal Cancer Consortium study showed the OR estimate of 1.08 per rs 11676348 risk allele, indicating a very weak association with overall colorectal cancer. ${ }^{221}$ When colorectal cancer was classified by immune response features, the association of the risk allele was stronger (OR estimate of 1.47 per risk allele) and specific for colorectal cancer subtype with Crohn's-like lymphoid reaction, but not for subtype without Crohn's-like lymphoid reaction.

and reduce sample selection bias in MPE research. In addition, a causal inference method such as inverse probability weighting can be used to reduce selection bias due to specimen availability. ${ }^{131224225}$ Second, MPE research uses disease subtyping (ie, multiple disease subtypes), hence inherently facing the issue of multiple hypothesis testing. To address the multiple hypothesis testing issue, it has been recommended that investigators set a heterogeneity test comparing subtype-specific associations as primary hypothesis testing. ${ }^{55}$ Proper utilisation and practice of statistical analysis can also mitigate this weakness. Third, there are measurement errors in bioassays. Hence, it is critical to ensure assay validity and performance. These challenges affect generalisability of findings. Currently, the studies described in table 2 represent rare examples of immunology-MPE research, for which a replication analysis may not easily be conducted. To increase overall sample size, statistical power and robustness

\begin{tabular}{|l|l|}
\hline Themes & Implementation \\
Strategies
\end{tabular}

\begin{tabular}{|c|c|c|}
\hline $\begin{array}{l}\text { Theme 1: Assess } \\
\text { significance of } \\
\text { immune features }\end{array}$ & $\begin{array}{l}\text { Aim 1: Develop robust } \\
\text { biomarkers to assess } \\
\text { tumour immunity }\end{array}$ & $\begin{array}{l}\text { Strategy } 1 \text { : Implement } \\
\text { and monitor immune } \\
\text { biomarkers }\end{array}$ \\
\hline $\begin{array}{l}\text { Theme 2: Assess } \\
\text { influence of exposures } \\
\text { (e.g., drugs) on tumour- } \\
\text { immune interactions }\end{array}$ & $\begin{array}{l}\text { Aim 2: Design integrative } \\
\text { analyses of epidemiological, } \\
\text { clinical, tumour molecular, } \\
\text { and immune characteristics }\end{array}$ & $\begin{array}{l}\text { Strategy 2: Evaluate } \\
\text { clinical practice schemes } \\
\text { by means of comparative } \\
\text { effectiveness research }\end{array}$ \\
\hline $\begin{array}{l}\text { Theme 3: Harness } \\
\text { immune system for } \\
\text { prevention and } \\
\text { therapy }\end{array}$ & $\begin{array}{l}\text { Aim 3: Design clinical trials } \\
\text { to assess efficacy of } \\
\text { immuno-prevention/therapy, } \\
\text { and role of immune analysis }\end{array}$ & $\begin{array}{l}\text { Strategy 3: Optimise } \\
\text { clinical practice schemes } \\
\text { based on new evidence }\end{array}$ \\
\hline
\end{tabular}

Figure 5 Roadmap of integrative immunology-molecular pathological epidemiology (MPE) to precision medicine. Three themes are set to start integrated immunology-MPE research and accomplish three specific aims. Based on data from research for the three specific aims, strategies 1 through 3 will help us implement, monitor and optimise tumour immunity testing for clinical use. of findings, a consortium should be formed to pool data from multiple studies. It may also be feasible to synthesise population health registries into global-scale MPE databases in the future. ${ }^{226}$

There are also challenges specific to the emerging field of immunology-MPE. While integration of tumour molecular pathology into epidemiology has been progressing since the $1990 \mathrm{~s},{ }^{145}$ integration of cancer immunology into epidemiology has lagged behind due to several reasons. Importantly, the immune system and its interactions with tumour are inherently complex. Hence, it is very challenging to develop a standardised laboratory test for detailed phenotyping and precise measurement of immune status in the tumour microenvironment. For this reason, it is difficult to implement detailed analyses of tumour-immune interactions in clinical settings and large-scale studies. Nonetheless, the emerging field of immunology-MPE can address this unmet need. Tackling many unanswered questions on effects of exposures on tumour-immune interactions are important in our efforts to improve our understanding of cancer and develop strategies for cancer prevention and treatment. Indeed, efforts to perform cancer immunity analyses using tissue resources in population-based studies have been ongoing. A number of analytic methods that use high-throughput tumour omics platforms to assess tumour-immune cell interactions are available. $^{227}$ Infiltrates of various immune cell types can be quantified using transcriptome profiling of tumour tissue that contains immune cells. ${ }^{228} 229$ In addition, DNA or RNA sequencing-based methods targeting $\mathrm{T}$ cell receptor genes (such as TRB; T cell receptor $\beta)^{230-233}$ may have considerable potential in largescale population-based studies. Data analysis methods such as network analysis can be applied to tumour immune response data in a large-scale study. ${ }^{189}$ There is also an opportunity to incorporate digital pathology and image analysis technologies on tissue specimens. In vivo microscopic technologies, which can be used together with endoscopies, ${ }^{234} 235$ will revolutionise biomedical and population studies of neoplasms, especially premalignant lesions. ${ }^{21} 85$ 236-239 As various omics analysis platforms have recently been applied to single cell analyses, ${ }^{240}$ there are open opportunities to use single cell analyses on a large number of cells (including immune cells) within a tumour in a large number of people; however, there exist considerable challenges in cost and feasibility of such a study.

In addition, there is a scarcity of interdisciplinary experts and education programmes integrating areas of epidemiology, pathology and immunology. This scarcity causes difficulty in planning and execution of transdisciplinary research including immunology-MPE projects. The scarcity of interdisciplinary experts is both a cause and consequence of the paucity of interdisciplinary training programmes. While population health scientists need education in immunology and pathobiology, wet laboratory scientists also need education in study design, epidemiology and statistics. Development of an interdisciplinary education system in public health and medical schools has been proposed to bridge this gap. ${ }^{52}$ Such a new system should encompass pathology and epidemiology, and naturally integrate immunology, considering its importance in many human diseases.

As another challenge, funding mechanisms also need to be adapted and optimised to fairly evaluate transdisciplinary science. The current peer-review system relies on evaluations of research proposals by researchers most of whom are experts in traditional disciplines. In addition, funding agencies (such as US National Institutes of Health and Cancer Research UK) have organisational structures mainly based on traditional disciplines, typically disease-based disciplines (but not method-based disciplines). Therefore, it is plausible that transdisciplinary research 
proposals may not be duly evaluated in light of their potential paradigm-shifting impact. Indeed, transdisciplinary research has been associated with lower funding success despite its stronger scientific impact compared with traditional discipline-bound research. $^{241}$

\section{OPPORTUNITIES AND FUTURE DIRECTIONS}

There are ample opportunities, given the importance of immunity in cancer, evidence for immunomodulatory roles of many exposures and the early rising phase of the immunology-MPE field. Thus far, only a limited number of studies have been conducted in the area, and hence, novelty of the integrative immunology-MPE approach remains relatively high. In addition, new methodologies of immune cell analyses can be incorporated in research. For instance, in vivo pathology technologies are promising tools that can expand the immunology-MPE model as discussed above.

Combining tumour tissue assessment with analyses of normal tissue and other biospecimens including peripheral blood, sputum, urine and other body fluids can add new dimensions to immunology-MPE research. For instance, immune cell analyses such as multicolour flow cytometry can be performed on those body fluid specimens. In addition, omics approaches, such as epigenomic, transcriptomic, proteomic and metabolomic analysis of circulating peripheral blood cells (and/or plasma), ${ }^{242-245}$ may enable multilevel studies on the status of the immune system, and together with tissue analyses, improve our understanding of influences of the systemic and local immune system status on cancer development and progression. It should be noted that circulating peripheral blood cells consist of many different cell types, and those omic data on circulating cells substantially depend on cellular compositions and their activation status. Recent advances in liquid biopsy provide new approaches to repeatedly and non-invasively interrogate the dynamic evolution of the molecular profiles of human cancers, through analyses of circulating tumour cells (CTCs), circulating tumour DNA (ctDNA) and exosomes containing various biomolecules. $^{3}{ }^{246-251}$ Dysregulation of immune regulators has been detected in CTCs, ${ }^{252}$ and mutational profile in ctDNA has been suggested as a useful marker for monitoring immunotherapy response. ${ }^{253}$ Therefore, applications of liquid biopsies can lead to new approaches for studying the dynamics of the tumour-immune-environmental interaction.

As another opportunity, microbiology can be integrated into immunology-MPE research. Microorganisms have been the most important targets of the immune system during human evolution. Therefore, an improved understanding of microbes and their interactions with the immune system can advance broad areas of immunology and medicine. Accumulating evidence indicates that microorganisms play important roles in classical infectious diseases and many chronic diseases, including cancer. $^{254-256}$ For example, many microorganisms have been implicated in tumourigenesis, including Epstein-Barr virus, HBV, HCV, HIV, human papillomavirus, human T-lymphotropic virus, polyoma viruses, Fusobacterium nucleatum, Helicobacter pylori, Schistosoma hematobium, among others. Notably, there is an intriguing link between the gut microbiota, including $F$. nucleatum and colorectal cancer. ${ }^{172} 257-264$ F. nucleatum may suppress the adaptive $\mathrm{T}$ cell response, ${ }^{265}$ and this immunosuppressive property may function in a way similar to the immune checkpoint in colorectal cancer. Supporting this, the amount of F. nucleatum in colorectal carcinoma has been inversely associated with $\mathrm{CD}^{+}$cell density in tumour. ${ }^{266}$ The abundance of
F. nucleatum in colorectal cancer tissue has been associated with the serrated neoplasia pathway, ${ }^{236267-270}$ a fibre-poor $\operatorname{diet}^{271}$ and unfavourable clinical outcomes. ${ }^{272} 273$ A recent study has shown persistence of $F$. nucleatum in metastatic colorectal tumour. ${ }^{274}$ The gut microbiota is a key factor in intestinal diseases and diseases in distant body sites, and even systemic diseases through their influences on metabolisms and immunity. ${ }^{254}$ Analyses of microbiota can be conducted using oral swab, stool and normal and tumour tissue, ${ }^{275-277}$ and integrated into immunology-MPE research.

Emerging evidence indicates inter-related links between drugs, nutrition, microbiota, immunity and tumour evolution. Data from integrative research can be used for drug repurposing. ${ }^{278}$ Studies have shown that the gut microbiota has a profound effect on the efficacy of cancer chemotherapy and immunotherapy. ${ }^{279-283}$ Frequent use of antibiotics has been associated with an increased risk of colorectal adenomas. ${ }^{284}$ Combined with pharmacological, nutritional, social and behavioural sciences, ${ }^{144} 149285-287$ effects of medications, nutrients, socioeconomic status and other exposures on tumour-microbe-immune interactions can be examined.

\section{CONCLUSIONS}

Given the unquestionable importance of the immune system in health and disease, immunology needs to be fully integrated into pathobiological population health science such as MPE. This integration, which has the potential to facilitate the realisation of precision medicine, has been hindered by the complex nature of the immune system and difficulty in developing standardised laboratory methods to assess tumour-immune interactions. Nonetheless, these technical challenges can be surmounted, and research efforts have started to integrate tumour immunology into MPE. To foster this integration, we must develop transdisciplinary education systems and new funding mechanisms. In the next decade, recognised as a discrete scientific field, immunology-MPE will play an increasingly important role in medicine and health sciences, as this field represents one of the priority areas in cancer research. ${ }^{288}$ Immunology-MPE research will provide novel evidence for roles of the immune systems in health and diseases at a population scale. Figure 5 illustrates a roadmap of integrative immunology-MPE research in order for us to realise precision medicine and exert clinical impact. Ultimately, integrative immunology-MPE research will offer new insights for the development of intervention strategies harnessing the immune system towards precision prevention and treatment.

\section{Author affiliations}

${ }^{1}$ Program in MPE Molecular Pathological Epidemiology, Department of Pathology, Brigham and Women's Hospital, Harvard Medical School, Boston, Massachusetts, USA

${ }^{2}$ Department of Oncologic Pathology, Dana-Farber Cancer Institute, Harvard Medical School, Boston, Massachusetts, USA

${ }^{3}$ Department of Epidemiology, Harvard T.H. Chan School of Public Health, Boston, Massachusetts, USA

${ }^{4}$ Broad Institute of Massachusetts Institute of Technology and Harvard, Cambridge, Massachusetts, USA

${ }^{5}$ Public Health Sciences Division, Fred Hutchinson Cancer Research Center, Seattle, Washington, USA

${ }^{6}$ Department of Epidemiology, University of Washington, Seattle, Washington, USA

${ }^{7}$ American Society for Clinical Pathology, Chicago, Illinois, USA

${ }^{8}$ Department of Nutrition, Harvard T.H. Chan School of Public Health, Boston, Massachusetts, USA

${ }^{9}$ Channing Division of Network Medicine, Department of Medicine, Brigham and Women's Hospital, Harvard Medical School, Boston, Massachusetts, USA

${ }^{10}$ Department of Biostatistics, Harvard T.H. Chan School of Public Health, Boston, Massachusetts, USA

${ }^{11}$ Department of Medical Oncology, Dana-Farber Cancer Institute, Harvard Medical School, Boston, Massachusetts, USA 
${ }^{12}$ Department of Medicine, Brigham and Women's Hospital, Harvard Medical School, Boston, Massachusetts, USA

${ }^{13}$ Department of Immunology and Infectious Diseases, Harvard T.H. Chan School of Public Health, Boston, Massachusetts, USA

${ }^{14}$ Clinical and Translational Epidemiology Unit, Massachusetts General Hospital, Boston, Massachusetts, USA

${ }^{15}$ Division of Gastroenterology, Massachusetts General Hospital, Harvard Medical School, Boston, Massachusetts, USA

Contributors RN, MG, WSG and MS contributed equally. SO developed the main concept of the manuscript. SO, AIP, UP and RN wrote grant applications. All authors contributed to review and revision, and approved the final manuscript.

Funding This work was supported in part by grants from the USA National Institutes of Health (R35 CA197735 (to SO), K07 CA172298 (to AIP), U01 CA137088 (to UP) and K07 CA190673 (to RN)) and Nodal Award (to SO) from the Dana-Farber Harvard Cancer Center.

Competing interests None declared.

Provenance and peer review Commissioned; externally peer reviewed.

(c) Article author(s) (or their employer(s) unless otherwise stated in the text of the article) 2018. All rights reserved. No commercial use is permitted unless otherwise expressly granted.

\section{REFERENCES}

1 Galon J, Angell HK, Bedognetti D, et al. The continuum of cancer immunosurveillance: prognostic, predictive, and mechanistic signatures. Immunity 2013;39:11-26.

2 Smyth MJ, Ngiow SF, Ribas A, et al. Combination cancer immunotherapies tailored to the tumour microenvironment. Nat Rev Clin Oncol 2016;13:143-58.

3 Mohme M, Riethdorf S, Pantel K. Circulating and disseminated tumour cells - mechanisms of immune surveillance and escape. Nat Rev Clin Oncol 2017; 14:155-67

4 Gubin MM. Cancer Immunology and Immunotherapy: taking a place in mainstream oncology keystone symposia meeting summary. Cancer Immunol Res 2017;5:434-8.

5 Marzbani $\mathrm{E}$, Inatsuka $\mathrm{C}$, Lu H, et al. The invisible arm of immunity in common cancer chemoprevention agents. Cancer Prev Res 2013;6:764-73.

6 Melief CJ, van Hall T, Arens R, et al. Therapeutic cancer vaccines. J Clin Invest 2015;125:3401-12

7 Ott PA, Hu Z, Keskin DB, et al. An immunogenic personal neoantigen vaccine for patients with melanoma. Nature 2017:547:217-21.

8 Sahin U, Derhovanessian E, Miller M, et al. Personalized RNA mutanome vaccines mobilize poly-specific therapeutic immunity against cancer. Nature 2017;547:222-6.

9 Kensler TW, Spira A, Garber JE, et al. Transforming Cancer Prevention through Precision Medicine and Immune-oncology. Cancer Prev Res 2016;9:2-10.

10 Blomain ES, Waldman SA. Does obesity promote the development of colorectal cancer? Expert Rev Anticancer Ther 2016;16:465-7.

11 Umar A, Steele VE, Menter DG, et al. Mechanisms of nonsteroidal anti-inflammatory drugs in cancer prevention. Semin Oncol 2016:43:65-77.

12 Friedenreich CM, Neilson HK, Farris MS, et al. Physical activity and cancer outcomes: a precision medicine approach. Clin Cancer Res 2016;22:4766-75.

13 Drew DA, Cao Y, Chan AT. Aspirin and colorectal cancer: the promise of precision chemoprevention. Nat Rev Cancer 2016;16:173-86.

14 Dou R, Ng K, Giovannucci EL, et al. Vitamin D and colorectal cancer: molecular, epidemiological and clinical evidence. Br J Nutr 2016;115:1643-60.

15 Zitvogel L, Pietrocola F, Kroemer G. Nutrition, inflammation and cancer. Nat Immunol 2017; 18:843-50.

16 Koelwyn GJ, Quail DF, Zhang X, et al. Exercise-dependent regulation of the tumour microenvironment. Nat Rev Cancer 2017;17:620-32.

17 Renehan AG, Zwahlen M, Egger M. Adiposity and cancer risk: new mechanistic insights from epidemiology. Nat Rev Cancer 2015;15:484-98.

18 Palesh 0, Demark-Wahnefried W, Mustian K, et al. Conducting cancer control and survivorship research via cooperative groups: a report from the American Society of Preventive Oncology. Cancer Epidemiol Biomarkers Prev 2011;20:1050-5.

19 Kushi LH, Doyle C, McCullough M, et al. American Cancer Society Guidelines on nutrition and physical activity for cancer prevention: reducing the risk of cancer with healthy food choices and physical activity. CA Cancer J Clin 2012;62:30-67.

20 Elena JW, Travis LB, Simonds NI, et al. Leveraging epidemiology and clinical studies of cancer outcomes: recommendations and opportunities for translational research. J Natl Cancer Inst 2013;105:85-94.

21 Spira A, Yurgelun MB, Alexandrov L, et al. Precancer atlas to drive precision prevention trials. Cancer Res 2017;77:1510-41.

22 Febbo PG, Ladanyi M, Aldape KD, et al. NCCN Task Force report: evaluating the clinical utility of tumor markers in oncology. J Natl Compr Canc Netw 2011;9(Suppl 5):S1-32.
23 deLeeuw RJ, Kost SE, Kakal JA, et al. The prognostic value of FoxP3+ tumorinfiltrating lymphocytes in cancer: a critical review of the literature. Clin Cancer Res 2012;18:3022-9.

24 Nosho K, Baba Y, Tanaka N, et al. Tumour-infiltrating T-cell subsets, molecular changes in colorectal cancer, and prognosis: cohort study and literature review. J Pathol 2010;222:350-66.

25 Saito T, Nishikawa H, Wada H, et al. Two FOXP3(+)CD4(+) T cell subpopulations distinctly control the prognosis of colorectal cancers. Nat Med 2016;22:679-84.

26 Galon J, Pagès F, Marincola FM, et al. Cancer classification using the Immunoscore: a worldwide task force. J Trans/ Med 2012;10:205.

27 Galon J, Mlecnik B, Bindea G, et al. Towards the introduction of the 'Immunoscore' in the classification of malignant tumours. J Pathol 2014;232:199-209.

28 Wirta EV, Seppälä T, Friman M, et al. Immunoscore in mismatch repair-proficient and -deficient colon cancer. J Patho/ Clin Res 2017;3:203-13.

29 Ogino S, Galon J, Fuchs CS, et al. Cancer immunology--analysis of host and tumor factors for personalized medicine. Nat Rev Clin Oncol 2011;8:711-9.

30 Mlecnik B, Bindea G, Angell HK, et al. Integrative analyses of colorectal cancer show immunoscore is a stronger predictor of patient survival than microsatellite instability. Immunity 2016;44:698-711.

31 Llosa NJ, Cruise M, Tam A, et al. The vigorous immune microenvironment of microsatellite instable colon cancer is balanced by multiple counter-inhibitory checkpoints. Cancer Discov 2015;5:43-51.

32 Giannakis M, Mu XJ, Shukla SA, et al. Genomic correlates of immune-cell infiltrates in colorectal carcinoma. Cell Rep 2016:15:857-65.

33 Li SK, Martin A. Mismatch repair and colon cancer: mechanisms and therapies explored. Trends Mol Med 2016:22:274-89.

34 Taieb J, Le Malicot K, Shi Q, et al. Prognostic value of BRAF and KRAS mutations in MSI and MSS stage III colon cancer. J Nat/ Cancer Inst 2017;109:djw272.

35 Le DT, Uram JN, Wang H, et al. PD-1 blockade in tumors with mismatch-repair deficiency. N Engl J Med 2015:372:2509-20.

36 Le DT, Durham JN, Smith KN, et al. Mismatch repair deficiency predicts response of solid tumors to PD-1 blockade. Science 2017:357:409-13.

37 Akbay EA, Koyama S, Carretero J, et al. Activation of the PD-1 pathway contributes to immune escape in EGFR-driven lung tumors. Cancer Discov 2013:3:1355-63

38 Mittendorf EA, Philips AV, Meric-Bernstam F, et al. PD-L1 expression in triplenegative breast cancer. Cancer Immunol Res 2014:2:361-70.

39 Parsa AT, Waldron JS, Panner A, et al. Loss of tumor suppressor PTEN function increases B7-H1 expression and immunoresistance in glioma. Nat Med 2007:13:84-8.

40 Xu C, Fillmore CM, Koyama S, et al. Loss of Lkb1 and Pten leads to lung squamous cell carcinoma with elevated PD-L1 expression. Cancer Cell 2014;25:590-604.

41 Teng MW, Ngiow SF, Ribas A, et al. Classifying cancers based on T-cell infiltration and PD-L1. Cancer Res 2015:75:2139-45.

42 Zhang Y, Chen L. Classification of advanced human cancers based on Tumor Immunity in the MicroEnvironment (TIME) for cancer immunotherapy. JAMA Oncol $2016 ; 2: 1403-4$

43 Uyttenhove C, Pilotte L, Théate I, et al. Evidence for a tumoral immune resistance mechanism based on tryptophan degradation by indoleamine 2,3-dioxygenase. Nat Med 2003:9:1269-74

44 Antonioli L, Blandizzi C, Pacher P, et al. Immunity, inflammation and cancer: a leading role for adenosine. Nat Rev Cancer 2013:13:842-57.

45 Platten M, Wick W, Van den Eynde BJ. Tryptophan catabolism in cancer: beyond IDO and tryptophan depletion. Cancer Res 2012;72:5435-40.

46 Sippel TR, White J, Nag K, et al. Neutrophil degranulation and immunosuppression in patients with GBM: restoration of cellular immune function by targeting arginase I. Clin Cancer Res 2011:17:6992-7002.

47 Colegio OR, Chu NQ, Szabo AL, et al. Functional polarization of tumour-associated macrophages by tumour-derived lactic acid. Nature 2014:513:559-63.

48 Brandacher $G$, Perathoner $A$, Ladurner $R$, et al. Prognostic value of indoleamine 2,3-dioxygenase expression in colorectal cancer: effect on tumor-infiltrating $T$ cells. Clin Cancer Res 2006;12:1144-51.

49 Spranger S, Spaapen RM, Zha Y, et al. Up-regulation of PD-L1, IDO, and T(regs) in the melanoma tumor microenvironment is driven by CD8(+) T cells. Sci Trans/ Med 2013;5:200ra116.

50 Chang CH, Qiu J, O'Sullivan D, et al. Metabolic competition in the tumor microenvironment is a driver of cancer progression. Cell 2015;162:1229-41.

51 loannidis JP. How to make more published research true. PLoS Med 2014;11:e1001747.

52 Ogino S, King EE, Beck AH, et al. Interdisciplinary education to integrate pathology and epidemiology: towards molecular and population-level health science. Am J Epidemiol 2012:176:659-67.

53 Ogino S, Stampfer M. Lifestyle factors and microsatellite instability in colorectal cancer: the evolving field of molecular pathological epidemiology. J Natl Cancer Inst 2010:102:365-7.

54 Ogino S, Chan AT, Fuchs CS, et al. Molecular pathological epidemiology of colorectal neoplasia: an emerging transdisciplinary and interdisciplinary field. Gut 2011;60:397-411 
55 Ogino S, Nishihara R, VanderWeele TJ, et al. Review article: the role of molecular pathological epidemiology in the study of neoplastic and non-neoplastic diseases in the era of precision medicine. Epidemiology 2016;27:602-11.

56 Hughes LAE, Simons C, van den Brandt PA, et al. Lifestyle, diet, and colorectal cancer risk according to (epi)genetic instability: current evidence and future directions of molecular pathological epidemiology. Curr Colorectal Cancer Rep 2017;13:455-69.

57 Lochhead P, Chan AT, Giovannucci E, et al. Progress and opportunities in molecular pathological epidemiology of colorectal premalignant lesions. Am J Gastroenterol 2014;109:1205-14.

58 Roy HK, Turzhitsky V, Wali R, et al. Spectral biomarkers for chemoprevention of colonic neoplasia: a placebo-controlled double-blinded trial with aspirin. Gut 2017:66:285-92.

59 Lochhead P, Chan AT, Nishihara R, et al. Etiologic field effect: reappraisal of the field effect concept in cancer predisposition and progression. Mod Pathol 2015;28:14-29.

60 Wang M, Spiegelman D, Kuchiba A, et al. Statistical methods for studying disease subtype heterogeneity. Stat Med 2016;35:782-800.

61 Wang M, Kuchiba A, Ogino S. A Meta-regression method for studying etiological heterogeneity across disease subtypes classified by multiple biomarkers. Am J Epidemiol 2015;182:263-70.

62 Chatterjee N, Sinha S, Diver WR, et al. Analysis of cohort studies with multivariate and partially observed disease classification data. Biometrika 2010;97:683-98.

63 Chatterjee N. A two-stage regression model for epidemiological studies with multivariate disease classification data. J Am Stat Assoc 2004;99:127-38.

64 Begg CB, Orlow I, Zabor EC, et al. Identifying etiologically distinct sub-types of cancer: a demonstration project involving breast cancer. Cancer Med 2015:4:1432-9.

65 Zabor EC, Begg CB. A comparison of statistical methods for the study of etiologic heterogeneity. Stat Med 2017:36:4050-60.

66 Begg CB, Seshan VE, Zabor EC, et al. Genomic investigation of etiologic heterogeneity: methodologic challenges. BMC Med Res Methodol 2014;14:138.

67 Begg CB, Zabor EC, Bernstein JL, et al. A conceptual and methodological framework for investigating etiologic heterogeneity. Stat Med 2013;32:5039-52.

68 Rosner B, Glynn RJ, Tamimi RM, et al. Breast cancer risk prediction with heterogeneous risk profiles according to breast cancer tumor markers. Am J Epidemiol 2013;178:296-308.

69 Richiardi L, Barone-Adesi F, Pearce N. Cancer subtypes in aetiological research. Eur J Epidemiol 2017:32:353-61.

70 Nevo D, Nishihara R, Ogino S, et al. The competing risks Cox model with auxiliary case covariates under weaker missing-at-random cause of failure. Lifetime Data Anal 2017. doi: 10.1007/s10985-017-9401-8. [Epub ahead of print 4 Aug 2017].

71 Rescigno T, Micolucci L, Tecce MF, et al. Bioactive nutrients and nutrigenomics in age-related diseases. Molecules 2017;22:e105.

72 Curtin K, Slattery ML, Samowitz WS. CpG island methylation in colorectal cancer: past, present and future. Patholog Res Int 2011;2011:1-8.

73 Bishehsari F, Mahdavinia M, Vacca M, et al. Epidemiological transition of colorectal cancer in developing countries: environmental factors, molecular pathways, and opportunities for prevention. World J Gastroenterol 2014;20:6055-72.

74 Jiang MJ, Dai JJ, Gu DN, et al. Aspirin in pancreatic cancer: chemopreventive effects and therapeutic potentials. Biochim Biophys Acta 2016;1866:163-76.

75 Martinez-Useros J, Garcia-Foncillas J. Obesity and colorectal cancer: molecular features of adipose tissue. J Trans/ Med 2016;14:21.

76 Chia WK, Ali R, Toh HC. Aspirin as adjuvant therapy for colorectal cancer-reinterpreting paradigms. Nat Rev Clin Oncol 2012;9:561-70.

77 Campbell PT, Newton CC, Newcomb PA, et al. Association between body mass index and mortality for colorectal cancer survivors: overall and by tumor molecular phenotype. Cancer Epidemiol Biomarkers Prev 2015;24:1229-38

78 Serafino A, Sferrazza G, Colini Baldeschi A, et al. Developing drugs that target the Wnt pathway: recent approaches in cancer and neurodegenerative diseases. Expert Opin Drug Discov 2017;12:169-86.

79 Patil H, Saxena SG, Barrow CJ, et al. Chasing the personalized medicine dream through biomarker validation in colorectal cancer. Drug Discov Today 2017:22:111-9.

80 Kuroiwa-Trzmielina J, Wang F, Rapkins RW, et al. SNP rs16906252C > T is an expression and methylation quantitative trait locus associated with an increased risk of developing mgmt-methylated colorectal cancer. Clin Cancer Res 2016:22:6266-77.

81 Slattery ML, Lee FY, Pellatt AJ, et al. Infrequently expressed miRNAs in colorectal cancer tissue and tumor molecular phenotype. Mod Pathol 2017;30:1152-69.

82 Alnabulsi A, Murray GI. Integrative analysis of the colorectal cancer proteome: potential clinical impact. Expert Rev Proteomics 2016;13:917-27.

$83 \mathrm{Ku}$ CS, Cooper DN, Wu M, et al. Gene discovery in familial cancer syndromes by exome sequencing: prospects for the elucidation of familial colorectal cancer type $\mathrm{X}$. Mod Pathol 2012;25:1055-68

84 Hughes LA, Khalid-de Bakker CA, Smits KM, et al. The CpG island methylator phenotype in colorectal cancer: progress and problems. Biochim Biophys Acta 2012;1825:77-85.
85 Szylberg $\nvdash$, Janiczek M, Popiel A, et al. Serrated polyps and their alternative pathway to the colorectal cancer: a systematic review. Gastroenterol Res Pract 2015;2015:1-7

86 Kuipers EJ, Grady WM, Lieberman D, et al. Colorectal cancer. Nat Rev Dis Primers 2015;1:15065.

87 Gao C. Molecular pathological epidemiology in diabetes mellitus and risk of hepatocellular carcinoma. World J Hepatol 2016;8:1119-27.

88 Mehta AM, Osse M, Kolkman-Uljee S, et al. Molecular backgrounds of ERAP1 downregulation in cervical carcinoma. Anal Cell Pathol 2015;2015:1-5.

89 Hagland HR, Berg M, Jolma IW, et al. Molecular pathways and cellular metabolism in colorectal cancer. Dig Surg 2013:30:12-25.

90 Campbell PT, Deka A, Briggs P, et al. Establishment of the cancer prevention study II nutrition cohort colorectal tissue repository. Cancer Epidemiol Biomarkers Prev 2014;23:2694-702.

91 Buchanan DD, Win AK, Walsh MD, et al. Family history of colorectal cancer in BRAF p.V600E-mutated colorectal cancer cases. Cancer Epidemiol Biomarkers Prev 2013:22:917-26

92 Chen IC, Lee KH, Hsu YH, et al. Expression Pattern and Clinicopathological Relevance of the Indoleamine 2,3-Dioxygenase 1/Tryptophan 2,3-Dioxygenase Protein in Colorectal Cancer. Dis Markers 2016;2016:1-9

93 Lee DH, Keum N, Giovannucci EL. Colorectal Cancer Epidemiology in the Nurses' Health Study. Am J Public Health 2016;106:1599-607.

94 Li YY, Ge QX, Cao J, et al. Association of Fusobacterium nucleatum infection with colorectal cancer in Chinese patients. World J Gastroenterol 2016;22:3227-33.

95 Venniyoor $A$. The most important questions in cancer research and clinical oncologyquestion 2-5. Obesity-related cancers: more questions than answers. Chin J Cancer 2017;36:18.

96 Li W, Qiu T, Ling Y, et al. Molecular pathological epidemiology of colorectal cancer in Chinese patients with KRAS and BRAF mutations. Oncotarget 2015;6:39607-13.

97 Zaidi N, Lupien L, Kuemmerle NB, et al. Lipogenesis and lipolysis: the pathways exploited by the cancer cells to acquire fatty acids. Prog Lipid Res 2013;52:585-9.

98 Sampedro GR, Bubeck Wardenburg J. Staphylococcus aureus in the intensive care unit: are these golden grapes ripe for a new approach? J Infect Dis 2017;215:S64-70

99 Chu SK, Yang HC. Interethnic DNA methylation difference and its implications in pharmacoepigenetics. Epigenomics 2017;9:1437-54.

100 Juárez M, Egoavil C, Rodríguez-Soler M, et al. KRAS and BRAF somatic mutations in colonic polyps and the risk of metachronous neoplasia. PLoS One 2017:12:e0184937.

101 Choi YJ, Lee DH, Han KD, et al. The relationship between drinking alcohol and esophageal, gastric or colorectal cancer: a nationwide population-based cohort study of South Korea. PLoS One 2017:12:e0185778.

102 Dong X, Hou Q, Chen Y, et al. Diagnostic value of the methylation of multiple gene promoters in serum in hepatitis B virus-related hepatocellular carcinoma. Dis Markers 2017;2017:1-6

103 Wang J, Shen C, Fu Y, et al. The associations between five polymorphisms of vascular endothelial growth factor and renal cell carcinoma risk: an updated meta-analysis. Onco Targets Ther 2017:10:1725-34.

104 Suh SS, Kim TK, Kim JE, et al. Anticancer activity of ramalin, a secondary metabolite from the antarctic lichen ramalina terebrata, against colorectal cancer cells. Molecules 2017:22:1361

105 Yuan W, Chen J, Shu Y, et al. Correlation of DAPK1 methylation and the risk of gastrointestinal cancer: a systematic review and meta-analysis. PLoS One 2017; 12:e0184959

106 Szpiech ZA, Strauli NB, White KA, et al. Prominent features of the amino acid mutation landscape in cancer. PLoS One 2017;12:e0183273.

107 Zhu CS, Huang WY, Pinsky PF, et al. The Prostate, Lung, Colorectal and Ovarian Cancer (PLCO) screening trial pathology tissue resource. Cancer Epidemiol Biomarkers Prev 2016:25:1635-42.

108 Ciesielski TH, Aldrich MC, Marsit CJ, et al. Transdisciplinary approaches enhance the production of translational knowledge. Trans/ Res 2017;182:123-34.

109 Kuller LH. Commentary: epidemiology - then and now. Am J Epidemiol 2016:183:372-80.

110 Reid BM, Permuth JB, Sellers TA. Epidemiology of ovarian cancer: a review. Cancer Biol Med 2017;14:9-32.

111 Lewis C, McQuaid S, Hamilton PW, et al. Building a 'repository of science': the importance of integrating biobanks within molecular pathology programmes. Eur J Cancer 2016:67:191-9.

112 Ryan E, Sheahan K, Creavin B, et al. The current value of determining the mismatch repair status of colorectal cancer: a rationale for routine testing. Crit Rev Oncol Hematol 2017;116:38-57.

113 Micolucci L, Rippo MR, Olivieri F, et al. Progress of research on microRNAs with diagnostic value in asbestos exposure: a call for method standardization. Biosci Trends 2017:11:105-9.

114 Ogino S, 2013. Molecular pathological epidemiology (MPE): Overview of its paradigm and wide applicability even without tumor tissue [abstract]. Proceedings of the Twelfth Annual AACR International Conference on Frontiers in Cancer Prevention Research. National Harbor, MD:Cancer Prev Res (Phila);27-30 Oct 2013;6: CN06-1 
115 Kuller LH, Bracken MB, Ogino S, et al. The role of epidemiology in the era of molecular epidemiology and genomics: summary of the 2013 AJEsponsored Society of Epidemiologic Research Symposium. Am J Epidemiol 2013:178:1350-4.

116 Epplein M, Bostick RM, Mu L, et al. Challenges and opportunities in international molecular cancer prevention research: an ASPO molecular epidemiology and the environment and international cancer prevention interest groups report. Cancer Epidemiol Biomarkers Prev 2014:23:2613-7.

117 Ogino S, 2017. Molecular pathological epidemiology of risk factors and CRC microbial and immune characteristics. [abstract]. Proceedings of the AACR Special Conference on Colorectal Cancer: From Initiation to Outcomes. Tampa, FL:Cancer Res; 17-20 Sep 2016;77: IA28

118 Ogino S, Campbell PT, Nishihara R, et al. Proceedings of the second international molecular pathological epidemiology (MPE) meeting. Cancer Causes Control 2015:26:959-72.

119 Campbell PT, Rebbeck TR, Nishihara R, et al. Proceedings of the third international molecular pathological epidemiology (MPE) meeting. Cancer Causes Control 2017;28:167-76

120 Drew DA, Chin SM, Gilpin KK, et al. ASPirin Intervention for the REDuction of colorectal cancer risk (ASPIRED): a study protocol for a randomized controlled trial. Trials 2017:18:50

121 Frouws MA, van Herk-Sukel MPP, Maas HA, et al. The mortality reducing effect of aspirin in colorectal cancer patients: Interpreting the evidence. Cancer Treat Rev 2017; 55:120-7.

122 Herbert K, Kerr R, Kerr DJ, et al. Are NSAIDs coming back to colorectal cancer therapy or not? Curr Colorectal Cancer Rep 2014;10:363-71.

123 Tougeron D, Sha D, Manthravadi S, et al. Aspirin and colorectal cancer: back to the future. Clin Cancer Res 2014:20:1087-94.

124 Hua X, Phipps Al, Burnett-Hartman AN, et al. Timing of aspirin and other nonsteroidal anti-inflammatory drug use among patients with colorectal cancer in relation to tumor markers and survival. I Clin Oncol 2017;35:2806-13.

$125 \mathrm{Li}$ P, Wu H, Zhang $\mathrm{H}$, et al. Aspirin use after diagnosis but not prediagnosis improves established colorectal cancer survival: a meta-analysis. Gut 2015;64:1419-25.

126 Chan AT, Ogino S, Fuchs CS. Aspirin use and survival after diagnosis of colorectal cancer. JAMA 2009:302:649-58.

127 Gray RT, Cantwell MM, Coleman HG, et al. Evaluation of PTGS2 expression, PIK3CA mutation, aspirin use and colon cancer survival in a population-based cohort study. Clin Transl Gastroenterol 2017;8:e91.

128 Liao X, Lochhead P, Nishihara R, et al. Aspirin use, tumor PIK3CA mutation, and colorectal-cancer survival. N Engl J Med 2012;367:1596-606.

129 Domingo E, Church DN, Sieber O, et al. Evaluation of PIK3CA mutation as a predictor of benefit from NSAID therapy in colorectal cancer. J Clin Oncol 2013:31:4297-305.

130 Mei ZB, Duan CY, Li CB, et al. Prognostic role of tumor PIK3CA mutation in colorectal cancer: a systematic review and meta-analysis. Ann Oncol 2016;27:1836-48.

131 Hamada T, Cao Y, Qian ZR, et al. Aspirin use and colorectal cancer survival according to tumor CD274 (programmed cell death 1 ligand 1) expression status. J Clin Oncol 2017;35:1836-44.

132 Stewart BW, Bray F, Forman D, et al. Cancer prevention as part of precision medicine: 'plenty to be done'. Carcinogenesis 2016;37:2-9.

133 Meyskens FL, Mukhtar H, Rock CL, et al. Cancer prevention: obstacles, challenges and the road ahead. J Natl Cancer Inst 2016;108:dju309.

134 Wild CP, Bucher JR, de Jong BW, et al. Translational cancer research: balancing prevention and treatment to combat cancer globally. J Natl Cancer Inst 2015;107:1-5.

135 Sawhney MS, Farrar WD, Gudiseva S, et al. Microsatellite instability in interval colon cancers. Gastroenterology 2006;131:1700-5.

136 Arain MA, Sawhney M, Sheikh S, et al. CIMP status of interval colon cancers: another piece to the puzzle. Am J Gastroenterol 2010;105:1189-95.

137 Nishihara R, Wu K, Lochhead P, et al. Long-term colorectal-cancer incidence and mortality after lower endoscopy. N Engl J Med 2013;369:1095-105.

138 Stoffel EM, Erichsen R, Frøslev T, et al. Clinical and molecular characteristics of post-colonoscopy colorectal cancer: a population-based study. Gastroenterology 2016;151:870-8.

139 Samowitz WS, Albertsen H, Sweeney C, et al. Association of smoking, CpG island methylator phenotype, and V600E BRAF mutations in colon cancer. J Natl Cancer Inst 2006;98:1731-8.

140 Limsui D, Vierkant RA, Tillmans $L S$, et al. Cigarette smoking and colorectal cancer risk by molecularly defined subtypes. J Natl Cancer Inst 2010;102:1012-22.

141 Poynter JN, Haile RW, Siegmund KD, et al. Associations between smoking, alcohol consumption, and colorectal cancer, overall and by tumor microsatellite instability status. Cancer Epidemiol Biomarkers Prev 2009;18:2745-50

142 Nishihara R, Morikawa T, Kuchiba A, et al. A prospective study of duration of smoking cessation and colorectal cancer risk by epigenetics-related tumor classification. Am J Epidemiol 2013:178:84-100.

143 Rozek LS, Herron CM, Greenson JK, et al. Smoking, gender, and ethnicity predict somatic BRAF mutations in colorectal cancer. Cancer Epidemiol Biomarkers Prev 2010;19:838-43.
144 Nishi A, Milner DA, Giovannucci EL, et al. Integration of molecular pathology, epidemiology and social science for global precision medicine. Expert Rev Mol Diagn 2016;16:11-23.

145 Hamada T, Keum N, Nishihara R, et al. Molecular pathological epidemiology: new developing frontiers of big data science to study etiologies and pathogenesis. J Gastroenterol 2017:52:265-75.

146 Chan AT, Ogino S, Fuchs CS. Aspirin and the risk of colorectal cancer in relation to the expression of COX-2. N Engl J Med 2007:356:2131-42.

147 Nishihara R, Lochhead P, Kuchiba A, et al. Aspirin use and risk of colorectal cancer according to BRAF mutation status. JAMA 2013;309:2563-71.

148 Fink SP, Yamauchi M, Nishihara R, et al. Aspirin and the risk of colorectal cancer in relation to the expression of 15-hydroxyprostaglandin dehydrogenase (HPGD). Sci Trans/ Med 2014:6:233re2.

149 Ogino S, Jhun I, Mata DA, et al. Integration of pharmacology, molecular pathology, and population data science to support precision gastrointestinal oncology. NPJ Precis Oncol 2017;1:40.

150 Nishihara R, VanderWeele TJ, Shibuya K, et al. Molecular pathological epidemiology gives clues to paradoxical findings. Eur J Epidemiol 2015:30:1129-35.

151 Choi Y, Park B, Jeong BC, et al. Body mass index and survival in patients with renal cell carcinoma: a clinical-based cohort and meta-analysis. Int J Cancer 2013;132:625-34.

152 Hakimi AA, Furberg $\mathrm{H}$, Zabor EC, et al. An epidemiologic and genomic investigation into the obesity paradox in renal cell carcinoma. J Natl Cancer Inst 2013;105:1862-70

153 Ogino S, Lochhead P, Chan AT, et al. Molecular pathological epidemiology of epigenetics: emerging integrative science to analyze environment, host, and disease. Mod Pathol 2013:26:465-84

154 Ogino S, Fuchs CS, Giovannucci E. How many molecular subtypes? Implications of the unique tumor principle in personalized medicine. Expert Rev Mol Diagn 2012;12:621-8

155 van Rooij N, van Buuren MM, Philips D, et al. Tumor exome analysis reveals neoantigen-specific T-cell reactivity in an ipilimumab-responsive melanoma. J Clin Oncol 2013;31:e439-42.

156 Basile D, Garattini SK, Bonotto M, et al. Immunotherapy for colorectal cancer: where are we heading? Expert Opin Biol Ther 2017;17:709-21

157 Cramer DW, Finn OJ. Epidemiologic perspective on immune-surveillance in cancer. Curr Opin Immunol 2011;23:265-71.

158 Rocca YS, Roberti MP, Arriaga JM, et al. Altered phenotype in peripheral blood and tumor-associated NK cells from colorectal cancer patients. Innate Immun 2013:19:76-85

159 Raine T, Liu JZ, Anderson CA, et al. Generation of primary human intestinal T cell transcriptomes reveals differential expression at genetic risk loci for immunemediated disease. Gut 2015:64:250-9.

160 Fridman WH, Pagès F, Sautès-Fridman C, et al. The immune contexture in human tumours: impact on clinical outcome. Nat Rev Cancer 2012;12:298-306.

161 Colussi D, Brandi G, Bazzoli F, et al. Molecular pathways involved in colorectal cancer: implications for disease behavior and prevention. Int J Mo/ SCi 2013;14:16365-85.

162 Kocarnik JM, Shiovitz S, Phipps Al. Molecular phenotypes of colorectal cancer and potential clinical applications. Gastroenterol Rep 2015;3:269-76.

163 Kudryavtseva AV, Lipatova AV, Zaretsky AR, et al. Important molecular genetic markers of colorectal cancer. Oncotarget 2016;7:53959-83.

164 Phipps Al, Limburg PJ, Baron JA, et al. Association between molecular subtypes of colorectal cancer and patient survival. Gastroenterology 2015;148:77-87.

165 Bijlsma MF, Sadanandam A, Tan P, et al. Molecular subtypes in cancers of the gastrointestinal tract. Nat Rev Gastroenterol Hepatol 2017;14:333-42.

166 Dienstmann R, Vermeulen L, Guinney J, et al. Consensus molecular subtypes and the evolution of precision medicine in colorectal cancer. Nat Rev Cancer 2017:17:79-92.

167 Sepulveda AR, Hamilton SR, Allegra CJ, et al. Molecular biomarkers for the evaluation of colorectal cancer: guideline from the American Society for Clinical Pathology, College of American Pathologists, Association for Molecular Pathology, and American Society of Clinical Oncology. J Mol Diagn 2017:19:187-225.

168 Giannakis M, Hodis E, Jasmine Mu X, Mu J, et al. RNF43 is frequently mutated in colorectal and endometrial cancers. Nat Genet 2014;46:1264-6.

169 Galon J, Costes A, Sanchez-Cabo F, et al. Type, density, and location of immune cells within human colorectal tumors predict clinical outcome. Science 2006:313:1960-4.

170 Di Caro G, Marchesi F, Laghi L, et al. Immune cells: plastic players along colorectal cancer progression. J Cell Mol Med 2013:17:1088-95.

171 Koshiol J, Lin SW. Can tissue-based immune markers be used for studying the natura history of cancer? Ann Epidemiol 2012;22:520-30.

172 Drewes JL, Housseau F, Sears CL. Sporadic colorectal cancer: microbial contributors to disease prevention, development and therapy. Br J Cancer 2016;115:273-80.

173 Lao VV, Grady WM. Epigenetics and colorectal cancer. Nat Rev Gastroenterol Hepatol 2011;8:686-700

174 Bardhan K, Liu K. Epigenetics and colorectal cancer pathogenesis. Cancers 2013;5:676-713. 
175 Zoratto F, Rossi L, Verrico M, et al. Focus on genetic and epigenetic events of colorectal cancer pathogenesis: implications for molecular diagnosis. Tumour Biol 2014;35:6195-206.

176 Okugawa Y, Grady WM, Goel A. Epigenetic Alterations in Colorectal Cancer: Emerging Biomarkers. Gastroenterology 2015;149:1204-25.

$177 \mathrm{Ng} \mathrm{JM}$, Yu J. Promoter hypermethylation of tumour suppressor genes as potential biomarkers in colorectal cancer. Int J Mol Sci 2015;16:2472-96.

178 Suzuki H, Yamamoto E, Maruyama R, et al. Biological significance of the CpG island methylator phenotype. Biochem Biophys Res Commun 2014;455:35-42.

179 Yamauchi M, Morikawa T, Kuchiba A, et al. Assessment of colorectal cancer molecular features along bowel subsites challenges the conception of distinct dichotomy of proximal versus distal colorectum. Gut 2012;61:847-54.

180 Yamauchi M, Lochhead P, Morikawa T, et al. Colorectal cancer: a tale of two sides or a continuum? Gut 2012;61:794-7

181 Bae JM, Kim JH, Cho NY, et al. Prognostic implication of the CpG island methylator phenotype in colorectal cancers depends on tumour location. Br J Cancer 2013;109:1004-12.

182 Jess P, Hansen IO, Gamborg M, et al. A nationwide Danish cohort study challenging the categorisation into right-sided and left-sided colon cancer. BMJ Open 2013;3:e002608

183 Rosty C, Young JP, Walsh MD, et al. Colorectal carcinomas with KRAS mutation are associated with distinctive morphological and molecular features. Mod Pathol 2013;26:825-34.

184 Rosty C, Young JP, Walsh MD, et al. PIK3CA activating mutation in colorectal carcinoma: associations with molecular features and survival. PLoS One 2013;8:e65479.

185 Phipps Al, Buchanan DD, Makar KW, et al. BRAF mutation status and survival after colorectal cancer diagnosis according to patient and tumor characteristics. Cancer Epidemiol Biomarkers Prev 2012;21:1792-8.

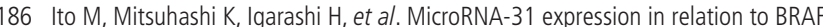
mutation, $\mathrm{CpG}$ island methylation and colorectal continuum in serrated lesions. Int J Cancer 2014;135:2507-15.

187 Mima K, Cao Y, Chan AT, et al. Fusobacterium nucleatum in colorectal carcinoma tissue according to tumor location. Clin Trans/ Gastroenterol 2016;7:e200.

188 Lee MS, Menter DG, Kopetz S. Right versus left colon cancer biology: integrating the consensus molecular subtypes. J Nat/ Compr Canc Netw 2017;15:411-9.

189 Nishihara R, Glass K, Mima K, et al. Biomarker correlation network in colorectal carcinoma by tumor anatomic location. BMC Bioinformatics 2017;18:304.

190 Loree JM, Pereira AAL, Lam M, et al. Classifying Colorectal Cancer by Tumor Location Rather than Sidedness Highlights a Continuum in Mutation Profiles and Consensus Molecular Subtypes. Clin Cancer Res 2018;24:1062-72.

191 Phipps Al, Chan AT, Ogino S. Anatomic subsite of primary colorectal cancer and subsequent risk and distribution of second cancers. Cancer 2013;119:3140-7.

192 Droeser RA, Hirt C, Viehl CT, et al. Clinical impact of programmed cell death ligand 1 expression in colorectal cancer. Eur J Cancer 2013;49:2233-42.

193 Taube JM, Klein A, Brahmer JR, et al. Association of PD-1, PD-1 ligands, and other features of the tumor immune microenvironment with response to anti-PD-1 therapy. Clin Cancer Res 2014;20:5064-74.

194 Masugi Y, Nishihara R, Yang J, et al. Tumour CD274 (PD-L1) expression and T cells in colorectal cancer. Gut 2017:66:1463-73.

195 Lee KS, Kwak Y, Ahn S, et al. Prognostic implication of CD274 (PD-L1) protein expression in tumor-infiltrating immune cells for microsatellite unstable and stable colorectal cancer. Cancer Immunol Immunother 2017;66:927-39.

196 Inaguma S, Lasota J, Wang Z, et al. Clinicopathologic profile, immunophenotype, and genotype of CD274 (PD-L1)-positive colorectal carcinomas. Mod Pathol 2017;30:278-85

197 Rosenbaum MW, Bledsoe JR, Morales-Oyarvide V, et al. PD-L1 expression in colorectal cancer is associated with microsatellite instability, BRAF mutation, medullary morphology and cytotoxic tumor-infiltrating lymphocytes. Mod Pathol 2016;29:1104-12.

198 Lee LH, Cavalcanti MS, Segal NH, et al. Patterns and prognostic relevance of PD-1 and PD-L1 expression in colorectal carcinoma. Mod Pathol 2016;29:1433-42.

199 Koganemaru S, Inoshita N, Miura Y, et al. Prognostic value of programmed death-ligand 1 expression in patients with stage III colorectal cancer. Cancer SCi 2017; 108:853-8

200 Marisa L, Svrcek M, Collura A, et al. The balance between cytotoxic T-cell lymphocytes and immune checkpoint expression in the prognosis of colon tumors. $J$ Natl Cancer Inst 2018:110:68-77.

201 Inaguma S, Lasota J, Felisiak-Golabek A, et al. Histopathological and genotypic characterization of metastatic colorectal carcinoma with PD-L1 (CD274)-expression: Possible roles of tumour micro environmental factors for CD274 expression. J Pathol Clin Res 2017:3:268-78

202 Masugi Y, Nishihara R, Hamada T, et al. Tumor PDCD1LG2 (PD-L2) expression and the lymphocytic reaciton to colorecal cancer. Cancer Immunol Res 2017;5:1046-55.

$203 \mathrm{Kim} \mathrm{JH}$, Kang GH. Molecular and prognostic heterogeneity of microsatellite-unstable colorectal cancer. World J Gastroenterol 2014;20:4230-43.

204 Benson AB, Venook AP, Cederquist L, et al. Colon cancer, version 1.2017, NCCN clinical practice guidelines in oncology. J Natl Compr Canc Netw 2017;15:370-98.
205 Le DT, Hubbard-Lucey VM, Morse MA, et al. A blueprint to advance colorectal cancer immunotherapies. Cancer Immunol Res 2017:5:942-9.

206 Lin JH, Giovannucci E. Environmental exposure and tumor heterogeneity in colorectal cancer risk and outcomes. Curr Colorectal Cancer Rep 2014:10:94-104.

207 Marley AR, Nan H. Epidemiology of colorectal cancer. Int J Mol Epidemiol Genet 2016;7:105-14.

208 Ogino S, Nosho K, Irahara N, et al. Lymphocytic reaction to colorectal cancer is associated with longer survival, independent of lymph node count, microsatellite instability, and CpG island methylator phenotype. Clin Cancer Res 2009;15:6412-20.

209 Edin S, Wikberg ML, Dahlin AM, et al. The distribution of macrophages with a M1 or M2 phenotype in relation to prognosis and the molecular characteristics of colorecta cancer. PLoS One 2012;7:e47045.

210 Ling A, Lundberg IV, Eklöf V, et al. The infiltration, and prognostic importance, of Th1 lymphocytes vary in molecular subgroups of colorectal cancer. J Pathol Clin Res 2016;2:21-31.

211 Ling A, Edin S, Wikberg ML, et al. The intratumoural subsite and relation of CD8(+) and FOXP3(+) T lymphocytes in colorectal cancer provide important prognostic clues. Br J Cancer 2014;110:2551-9.

212 Wangefjord S, Sundström M, Zendehrokh N, et al. Sex differences in the prognostic significance of KRAS codons 12 and 13, and BRAF mutations in colorectal cancer: a cohort study. Biol Sex Differ 2013;4:17

213 Rozek LS, Schmit SL, Greenson JK, et al. Tumor-infiltrating lymphocytes, crohn's-like lymphoid reaction, and survival from colorectal cancer. J Nat/ Cancer Inst 2016:108.

214 Mima K, Nishihara R, Nowak JA, et al. MicroRNA MIR21 and T cells in colorectal cancer. Cancer Immunol Res 2016:4:33-40.

215 Dou R, Nishihara R, Cao Y, et al. MicroRNA let-7, T Cells, and patient survival in colorectal cancer. Cancer Immunol Res 2016:4:927-35.

216 Kosumi K, Masugi Y, Yang J, et al. Tumor SQSTM1 (p62) expression and T cells in colorectal cancer. Oncoimmunology 2017;6:e1284720.

217 Prizment AE, Vierkant RA, Smyrk TC, et al. Cytotoxic T-cells and granzyme B associated with improved colorectal cancer survival in a prospective cohort of older women. Cancer Epidemiol Biomarkers Prev 2017:26:622-31.

218 Berntsson J, Svensson MC, Leandersson K, et al. The clinical impact of tumourinfiltrating lymphocytes in colorectal cancer differs by anatomical subsite: A cohort study. Int J Cancer 2017;141:1654-66.

219 Prizment AE, Vierkant RA, Smyrk TC, et al. Tumor eosinophil infiltration and improved survival of colorectal cancer patients: Iowa Women's Health Study. Mod Pathol 2016:29:516-27.

220 Song M, Nishihara R, Cao Y, et al. Marine $\omega$-3 polyunsaturated fatty acid intake and risk of colorectal cancer characterized by tumor-infiltrating T cells. JAMA Oncol 2016:2:1197-206.

221 Khalili $\mathrm{H}$, Gong J, Brenner $\mathrm{H}$, et al. Identification of a common variant with potential pleiotropic effect on risk of inflammatory bowel disease and colorectal cancer. Carcinogenesis 2015;36:999-1007

222 Peters U, Bien S, Zubair N. Genetic architecture of colorectal cancer. Gut 2015:64:1623-36

223 Song M, Nishihara R, Wang M, et al. Plasma 25-hydroxyvitamin D and colorectal cancer risk according to tumour immunity status. Gut 2016;65:296-304.

224 Seaman SR, White IR. Review of inverse probability weighting for dealing with missing data. Stat Methods Med Res 2013;22:278-95.

225 Liu L, Nevo D, Nishihara R, et al. Utility of inverse probability weighting in molecular pathological epidemiology. Eur J Epidemio/ 2017. doi: 10.1007/s10654-017-0346 8. [Epub ahead of print 20 Dec 2017].

226 Ogino S, Lochhead P, Giovannucci E, et al. Discovery of colorectal cancer PIK3CA mutation as potential predictive biomarker: power and promise of molecular pathological epidemiology. Oncogene 2014;33:2949-55.

227 Hackl H, Charoentong P, Finotello F, et al. Computational genomics tools for dissecting tumour-immune cell interactions. Nat Rev Genet 2016:17:441-58.

228 Yoshihara K, Shahmoradgoli M, Martínez E, et al. Inferring tumour purity and stroma and immune cell admixture from expression data. Nat Commun 2013:4:2612.

229 Gentles AJ, Newman AM, Liu CL, et al. The prognostic landscape of genes and infiltrating immune cells across human cancers. Nat Med 2015;21:938-45.

230 Benichou J, Ben-Hamo R, Louzoun Y, et al. Rep-Seq: uncovering the immunological repertoire through next-generation sequencing. Immunology 2012;135:183-91.

231 Safonova Y, Lapidus A, Lill J. IgSimulator: a versatile immunosequencing simulator Bioinformatics 2015;31:3213-5.

232 Howie B, Sherwood AM, Berkebile AD, et al. High-throughput pairing of T cell receptor $\alpha$ and $\beta$ sequences. Sci Trans/ Med 2015;7:301ra131.

233 Li B, Li T, Pignon JC, et al. Landscape of tumor-infiltrating T cell repertoire of human cancers. Nat Genet 2016;48:725-32.

234 Sako T, Kudo SE, Miyachi H, et al. A novel ability of endocytoscopy to diagnose histological grade of differentiation in T1 colorectal carcinomas. Endoscopy 2018:50:69-74.

235 Tearney GJ, Kang D. Introduction to biomedical optical imaging. Lasers Surg Med 2017:49:214

236 Rex DK, Ahnen DJ, Baron JA, et al. Serrated lesions of the colorectum: review and recommendations from an expert panel. Am J Gastroenterol 2012;107:1315-29. 
237 Haumaier F, Sterlacci W, Vieth M. Histological and molecular classification of gastrointestinal polyps. Best Pract Res Clin Gastroenterol 2017;31:369-79.

238 Ryan BM, Faupel-Badger JM. The hallmarks of premalignant conditions: a molecular basis for cancer prevention. Semin Oncol 2016;43:22-35.

239 Bettington M, Walker N, Rosty C, et al. Clinicopathological and molecular features of sessile serrated adenomas with dysplasia or carcinoma. Gut 2017;66:97-106.

240 Prakadan SM, Shalek AK, Weitz DA. Scaling by shrinking: empowering single-cell 'omics' with microfluidic devices. Nat Rev Genet 2017:18:345-61.

241 Bromham L, Dinnage R, Hua X. Interdisciplinary research has consistently lower funding success. Nature 2016;534:684-7.

242 Barrow TM, Michels KB. Epigenetic epidemiology of cancer. Biochem Biophys Res Commun 2014;455:70-83.

243 Zhou L, Wang K, Li Q, et al. Clinical proteomics-driven precision medicine for targeted cancer therapy: current overview and future perspectives. Expert Rev Proteomics 2016;13:367-81.

244 Thiele JA, Bethel K, Králíčková M, et al. Circulating tumor cells: fluid surrogates of solid tumors. Annu Rev Pathol 2017:12:419-47.

245 Townsend MK, Aschard H, De Vivo I, et al. Genomics, telomere length, epigenetics, and metabolomics in the nurses health studies. Am J Public Health 2016;106:1663-8.

246 Tan CR, Zhou L, El-Deiry WS. Circulating tumor cells versus circulating tumor DNA in colorectal cancer: pros and cons. Curr Colorectal Cancer Rep 2016;12:151-61.

247 Grillet F, Bayet E, Villeronce 0 , et al. Circulating tumour cells from patients with colorectal cancer have cancer stem cell hallmarks in ex vivo culture. Gut 2017;66:1802-10.

248 Olmedillas López S, García-Olmo DC, García-Arranz M, et al. KRAS G12V mutation detection by droplet digital PCR in circulating cell-free DNA of colorectal cancer patients. Int J Mol Sci 2016;17:484.

249 Nagai Y, Sunami E, Yamamoto Y, et al. LINE-1 hypomethylation status of circulating cell-free DNA in plasma as a biomarker for colorectal cancer. Oncotarget 2017;8:11906-16.

250 Siravegna G, Marsoni S, Siena S, et al. Integrating liquid biopsies into the management of cancer. Nat Rev Clin Oncol 2017;14:531-48.

251 Strickler JH, Loree JM, Ahronian LG, et al. Genomic Landscape of Cell-Free DNA in Patients with Colorectal Cancer. Cancer Discov 2018;8:164-73.

252 Mazel M, Jacot W, Pantel K, et al. Frequent expression of PD-L1 on circulating breast cancer cells. Mol Oncol 2015;9:1773-82.

253 Khagi Y, Goodman AM, Daniels GA, et al. Hypermutated circulating tumor DNA: correlation with response to checkpoint inhibitor-based immunotherapy. Clin Cancer Res 2017;23:5729-36.

254 Honda K, Littman DR. The microbiota in adaptive immune homeostasis and disease. Nature 2016;535:75-84.

255 Chen J, Domingue JC, Sears CL. Microbiota dysbiosis in select human cancers: Evidence of association and causality. Semin Immunol 2017;32:25-34.

256 Chen J, Pitmon E, Wang K. Microbiome, inflammation and colorectal cancer. Semin Immunol 2017;32:43-53.

257 Kostic AD, Gevers D, Pedamallu CS, et al. Genomic analysis identifies association of Fusobacterium with colorectal carcinoma. Genome Res 2012;22:292-8.

258 Castellarin M, Warren RL, Freeman JD, et al. Fusobacterium nucleatum infection is prevalent in human colorectal carcinoma. Genome Res 2012;22:299-306.

259 Dejea CM, Wick EC, Hechenbleikner EM, et al. Microbiota organization is a distinct feature of proximal colorectal cancers. Proc Natl Acad Sci U S A 2014;111:18321-6.

260 Nakatsu G, Li X, Zhou H, et al. Gut mucosal microbiome across stages of colorectal carcinogenesis. Nat Commun 2015;6:8727.

261 Nosho K, Sukawa Y, Adachi Y, et al. Association of Fusobacterium nucleatum with immunity and molecular alterations in colorectal cancer. World J Gastroenterol 2016;22:557-66

262 Yamaoka Y, Suehiro Y, Hashimoto S, et al. Fusobacterium nucleatum as a prognostic marker of colorectal cancer in a Japanese population. J Gastroentero/ 2017. doi: 10.1007/s00535-017-1382-6. [Epub ahead of print 19 Aug 2017].

263 Purcell RV, Visnovska M, Biggs PJ, et al. Distinct gut microbiome patterns associate with consensus molecular subtypes of colorectal cancer. Sci Rep 2017;7:11590.

264 Abed J, Emgård JE, Zamir G, et al. Fap2 mediates Fusobacterium nucleatum colorectal adenocarcinoma enrichment by binding to tumor-expressed Gal-GalNAc. Cell Host Microbe 2016;20:215-25
265 Kostic AD, Chun E, Robertson L, et al. Fusobacterium nucleatum potentiates intestinal tumorigenesis and modulates the tumor-immune microenvironment. Cell Host Microbe 2013;14:207-15.

266 Mima K, Sukawa Y, Nishihara R, et al. Fusobacterium nucleatum and T-cells in colorectal carcinoma. JAMA Oncol 2015;1:653-61.

267 East JE, Atkin WS, Bateman AC, et al. British Society of Gastroenterology position statement on serrated polyps in the colon and rectum. Gut 2017;66:1181-96.

268 Ito M, Kanno S, Nosho K, et al. Association of Fusobacterium nucleatum with clinical and molecular features in colorectal serrated pathway. Int $J$ Cancer 2015;137:1258-68.

269 Park CH, Han DS, Oh YH, Yh O, et al. Role of Fusobacteria in the serrated pathway of colorectal carcinogenesis. Sci Rep 2016;6:25271.

270 IJspeert JE, Vermeulen L, Meijer GA, et al. Serrated neoplasia-role in colorectal carcinogenesis and clinical implications. Nat Rev Gastroenterol Hepatol 2015;12:401-9.

271 Mehta RS, Nishihara R, Cao Y, et al. Association of dietary patterns with risk of colorectal cancer subtypes classified by Fusobacterium nucleatum in tumor tissue. JAMA Oncol 2017;3:921-7.

272 Tahara T, Yamamoto E, Suzuki H, et al. Fusobacterium in colonic flora and molecular features of colorectal carcinoma. Cancer Res 2014;74:1311-8.

273 Mima K, Nishihara R, Qian ZR, et al. Fusobacterium nucleatum in colorectal carcinoma tissue and patient prognosis. Gut 2016;65:1973-80.

274 Bullman S, Pedamallu CS, Sicinska E, et al. Analysis of Fusobacterium persistence and antibiotic response in colorectal cancer. Science 2017;358:1443-8.

275 Mima K, Ogino S, Nakagawa S, et al. The role of intestinal bacteria in the development and progression of gastrointestinal tract neoplasms. Surg Oncol 2017;26:368-76.

276 Yu J, Feng Q, Wong SH, et al. Metagenomic analysis of faecal microbiome as a tool towards targeted non-invasive biomarkers for colorectal cancer. Gut 2017;66:70-8

277 Flemer B, Warren RD, Barrett MP, et al. The oral microbiota in colorectal cancer is distinctive and predictive. Gut 2017. doi: 10.1136/gutjnl-2017-314814. [Epub ahead of print 7 Oct 2017].

278 Bertolini F, Sukhatme VP, Bouche G. Drug repurposing in oncology--patient and health systems opportunities. Nat Rev Clin Oncol 2015;12:732-42.

279 Sivan A, Corrales L, Hubert N, et al. Commensal Bifidobacterium promotes antitumor immunity and facilitates anti-PD-L1 efficacy. Science 2015;350:1084-9.

280 Vétizou M, Pitt JM, Daillère R, et al. Anticancer immunotherapy by CTLA-4 blockade relies on the gut microbiota. Science 2015;350:1079-84.

281 Yu T, Guo F, Yu Y, et al. Fusobacterium nucleatum promotes chemoresistance to colorectal cancer by modulating autophagy. Cell 2017;170:548-63.

282 Geller LT, Barzily-Rokni M, Danino T, et al. Potential role of intratumor bacteria in mediating tumor resistance to the chemotherapeutic drug gemcitabine. Science 2017:357:1156-60.

283 Gopalakrishnan V, Spencer CN, Nezi L, et al. Gut microbiome modulates response to anti-PD-1 immunotherapy in melanoma patients. Science 2018;359:97-103.

284 Cao Y, Wu K, Mehta R, et al. Long-term use of antibiotics and risk of colorectal adenoma. Gut 2018:67:672-8

285 Ashktorab H, Kupfer SS, Brim H, et al. Racial disparity in gastrointestinal cancer risk. Gastroenterology 2017;153:910-23.

286 Augustus GJ, Ellis NA. Race in cancer health disparities theme issue colorectal cance disparity in African Americans: risk factors and carcinogenic mechanisms. Am J Pathol. In Press. 2017.

287 Gardner K. The Science of Cancer Health Disparities: A Young Discipline with an Old Heritage. Am J Pathol 2018;188:268-70.

288 Jaffee EM, Dang CV, Agus DB, et al. Future cancer research priorities in the USA: a Lancet Oncology Commission. Lancet Oncol 2017;18:e653-706.

289 Cao Y, Nishihara R, Qian ZR, et al. Regular aspirin use associates with lower risk of colorectal cancers with low numbers of tumor-infiltrating lymphocytes. Gastroenterology 2016;151:879-92

290 Hanyuda A, Ogino S, Qian ZR, et al. Body mass index and risk of colorectal cancer according to tumor lymphocytic infiltrate. Int J Cancer 2016;139:854-68.

291 Liu L, Nishihara R, Qian ZR, et al. Association between inflammatory diet pattern and risk of colorectal carcinoma subtypes classified by immune responses to tumor. Gastroenterology 2017;153:1517-30 